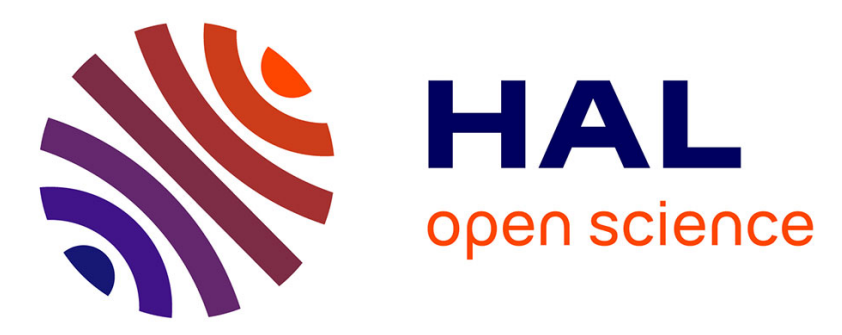

\title{
Comprehensive isotopic composition of atmospheric nitrate in the Atlantic Ocean boundary layer from $65^{\circ} \mathrm{S}$ to $79^{\circ} \mathrm{N}$
}

Samuel Morin, Joël Savarino, Markus M. Frey, Florent Domine, Hans-Werner Jacobi, L. Kaleschke, Jean M. F. Martins

\section{To cite this version:}

Samuel Morin, Joël Savarino, Markus M. Frey, Florent Domine, Hans-Werner Jacobi, et al.. Comprehensive isotopic composition of atmospheric nitrate in the Atlantic Ocean boundary layer from $65^{\circ} \mathrm{S}$ to $79^{\circ}$ N. Journal of Geophysical Research: Atmospheres, 2009, 114, pp.D05303. 10.1029/2008JD010696 . insu-00413235

\section{HAL Id: insu-00413235 \\ https://hal-insu.archives-ouvertes.fr/insu-00413235}

Submitted on 5 Mar 2021

HAL is a multi-disciplinary open access archive for the deposit and dissemination of scientific research documents, whether they are published or not. The documents may come from teaching and research institutions in France or abroad, or from public or private research centers.
L'archive ouverte pluridisciplinaire HAL, est destinée au dépôt et à la diffusion de documents scientifiques de niveau recherche, publiés ou non, émanant des établissements d'enseignement et de recherche français ou étrangers, des laboratoires publics ou privés. 


\title{
Comprehensive isotopic composition of atmospheric nitrate in the Atlantic Ocean boundary layer from $65^{\circ} \mathrm{S}$ to $79^{\circ} \mathrm{N}$
}

\author{
S. Morin, ${ }^{1,2}$ J. Savarino, ${ }^{1,2}$ M. M. Frey, ${ }^{1,2,3}$ F. Domine, ${ }^{1,2}$ H.-W. Jacobi, ${ }^{1,2,4}$ L. Kaleschke, ${ }^{5}$ \\ and J. M. F. Martins ${ }^{1,6}$ \\ Received 1 July 2008; revised 20 October 2008; accepted 29 December 2008; published 6 March 2009.
}

[1] The comprehensive isotopic composition of atmospheric nitrate (i.e., the simultaneous measurement of all its stable isotope ratios: ${ }^{15} \mathrm{~N} /{ }^{14} \mathrm{~N},{ }^{17} \mathrm{O} /{ }^{16} \mathrm{O}$ and ${ }^{18} \mathrm{O} /{ }^{16} \mathrm{O}$ ) has been determined for aerosol samples collected in the marine boundary layer (MBL) over the Atlantic Ocean from $65^{\circ} \mathrm{S}$ (Weddell Sea) to $79^{\circ} \mathrm{N}$ (Svalbard), along a ship-borne latitudinal transect. In nonpolar areas, the $\delta^{15} \mathrm{~N}$ of nitrate mostly deriving from anthropogenically emitted $\mathrm{NO}_{x}$ is found to be significantly different (from 0 to $6 \%$ ) from nitrate sampled in locations influenced by natural $\mathrm{NO}_{x}$ sources $(-4 \pm 2) \%$. The effects on $\delta^{15} \mathrm{~N}\left(\mathrm{NO}_{3}^{-}\right)$of different $\mathrm{NO}_{x}$ sources and nitrate removal processes associated with its atmospheric transport are discussed. Measurements of the oxygen isotope anomaly $\left(\Delta^{17} \mathrm{O}=\delta^{17} \mathrm{O}-0.52 \times \delta^{18} \mathrm{O}\right)$ of nitrate suggest that nocturnal processes involving the nitrate radical play a major role in terms of $\mathrm{NO}_{x}$ sinks. Different $\Delta^{17} \mathrm{O}$ between aerosol size fractions indicate different proportions between nitrate formation pathways as a function of the size and composition of the particles. Extremely low $\delta^{15} \mathrm{~N}$ values (down to $-40 \%$ ) are found in air masses exposed to snow-covered areas, showing that snowpack emissions of $\mathrm{NO}_{x}$ from upwind regions can have a significant impact on the local surface budget of reactive nitrogen, in conjunction with interactions with active halogen chemistry. The implications of the results are discussed in light of the potential use of the stable isotopic composition of nitrate to infer atmospherically relevant information from nitrate preserved in ice cores.

Citation: Morin, S., J. Savarino, M. M. Frey, F. Domine, H.-W. Jacobi, L. Kaleschke, and J. M. F. Martins (2009), Comprehensive isotopic composition of atmospheric nitrate in the Atlantic Ocean boundary layer from $65^{\circ} \mathrm{S}$ to $79^{\circ} \mathrm{N}, \mathrm{J}$. Geophys. Res., 114 , D05303, doi:10.1029/2008JD010696.

\section{Introduction}

[2] The nitrate ion is an ubiquitous chemical component of the atmosphere that plays a major role in the biogeochemical cycle of reactive nitrogen [Galloway et al., 2008; Duce et al., 2008]. Atmospheric nitrate (here defined as gasphase $\mathrm{HNO}_{3}$ and particulate $\mathrm{NO}_{3}^{-}$) mainly results from the transformation of gas-phase precursors. Nitrogen oxides $\left(\mathrm{NO}_{x}=\mathrm{NO}+\mathrm{NO}_{2}\right)$ produced by a number of processes such as combustion and lightning in the atmosphere [Schumann

\footnotetext{
${ }^{1}$ Institut National des Sciences de l'Univers, CNRS, Grenoble, France.

${ }^{2}$ Laboratoire de Glaciologie et Géophysique de l'Environnement, Université Joseph Fourier, Grenoble, France.

${ }^{3}$ Now at British Antarctic Survey, Natural Environment Research Council, Cambridge, UK.

${ }^{4}$ Alfred Wegener Institute for Polar and Marine Research, Bremerhaven, Germany.

${ }^{5}$ ZMAW, Institute of Oceanography, University of Hamburg, Hamburg, Germany.

${ }^{6}$ Laboratoire d'étude des Transferts en Hydrologie et Environnement, Université Joseph Fourier, Grenoble, France.
}

Copyright 2009 by the American Geophysical Union. 0148-0227/09/2008JD010696 and Huntrieser, 2007], biomass burning [FinlaysonPitts and Pitts, 2000] and soil processes [Davidson and Kingerlee, 1997] are ultimately converted to atmospheric nitrate through a number of chemical pathways, involving atmospheric oxidants such as ozone $\left(\mathrm{O}_{3}\right)$, the hydroxyl radical $(\mathrm{OH})$, peroxy radicals and halogen oxides. In addition to being key precursors of atmospheric nitrate, $\mathrm{NO}_{x}$ control the chemical production of $\mathrm{O}_{3}$, which in turn is a greenhouse gas and pollutant and contributes to the oxidative capacity of the atmosphere (i.e., the lifetime of organic compounds through the oxidative action of radicals such as OH or halogens) [Finlayson-Pitts and Pitts, 2000]. Atmospheric nitrate contributes to the load of atmospheric particulate matter (hence having an impact on climate [Intergovernmental Panel on Climate Change, 2007]) and, along with sulfate, to the acid rain phenomenon [FinlaysonPitts and Pitts, 2000]. Despite the onset of regulation policies in industrialized regions, the atmospheric $\mathrm{NO}_{x}$ and nitrate burden is increasing and predicted to continue to do so in many parts of the world [Bauer et al., 2007; van $\operatorname{der} A$ et al., 2008]. Understanding the chemical fate of $\mathrm{NO}_{x}$ is important to assess their impact on regional air quality, 
climate, and the oxidative capacity of the atmosphere [Brown et al., 2006].

[3] The environment of the Atlantic marine boundary layer (MBL) allows to study reactive nitrogen chemistry under a wide range of environmental conditions [Lelieveld et al., 2004; Virkkula et al., 2006a, 2006b; Read et al., 2008]. The proportion of the contributing sources of $\mathrm{NO}_{x}$ to its atmospheric budget vary as a function of latitude from mainly natural sources in low-latitude regions [Schumann and Huntrieser, 2007; van der A et al., 2008] to dominant anthropogenic influence at the latitude of Europe. At high latitudes the Atlantic Ocean is exposed to polar conditions. In recent years, it has been realized that in such regions snow covers could represent a source of $\mathrm{NO}_{x}$ to the overlying atmosphere [Honrath et al., 1999; Ridley et al., 2000; Jones et al., 2000; Beine et al., 2002], driven by the photolysis of nitrate in the snow [e.g., Dominé and Shepson, 2002; Grannas et al., 2007]. Further characteristics of the polar areas include the role of halogen radicals in triggering and catalyzing ozone depletion events in the spring [Simpson et al., 2007, and references therein]. Interactions of reactive halogen species (RHS) such as $\mathrm{BrO}$ with $\mathrm{NO}_{x}$ have been postulated, in particular through the formation of $\mathrm{BrONO}_{2}$, which could act as a reservoir species for both $\mathrm{NO}_{x}$ and RHS according to modeling studies [Evans et al., 2003; Simpson et al., 2007; Tas et al., 2008], but has never been directly measured.

[4] Oxygen and nitrogen stable isotope ratios of nitrate can be used to gain complementary information on the sources and sinks of atmospheric nitrate. Stable isotope ratios measurements are reported as relative differences in isotope ratios (on the $\delta$ scale),

$$
\delta=\frac{\mathrm{R}_{\text {sample }}}{\mathrm{R}_{\text {reference }}}-1
$$

where $\mathrm{R}$ represents the elemental ${ }^{17} \mathrm{O} /{ }^{16} \mathrm{O},{ }^{18} \mathrm{O} /{ }^{16} \mathrm{O}$ or ${ }^{15} \mathrm{~N} /{ }^{14} \mathrm{~N}$ ratio in the sample and in a reference, respectively. The reference for oxygen is the Standard Mean Ocean Water (SMOW) and for nitrogen it is atmospheric $\mathrm{N}_{2}$ [Böhlke et al., 2003, and references therein]. For practical reasons $\delta$ values are generally expressed in per mil(\%), as variations in isotopic ratios occur in a very narrow range.

[5] Nitrogen stable isotope ratios of atmospheric nitrate (expressed in terms of $\delta^{15} \mathrm{~N}$ ) are used to trace $\mathrm{NO}_{x}$ sources, because they imprint different $\delta^{15} \mathrm{~N}$ signatures [Kendall et al., 2007]. The conversion of $\mathrm{NO}_{x}$ to nitrate is thought to induce limited ${ }^{15} \mathrm{~N}$ isotopic fractionation [Freyer, 1991; Freyer et al., 1993]. Atmospheric nitrate removal during transport also potentially modifies its $\delta^{15} \mathrm{~N}$ [Freyer, 1991; Heaton et al., 2004; Michalski et al., 2005; Morin et al., 2008]. There is ongoing debate as to whether shifts in $\mathrm{NO}_{x}$ sources [Hastings et al., 2003], ${ }^{15} \mathrm{~N}$ partitionment within $\mathrm{NO}_{x}$ [Jarvis et al., 2008] or the effects of removal mechanisms during long-range transport of reactive nitrogen [Morin et al., 2008] are the main drivers of seasonal variations of $\delta^{15} \mathrm{~N}$ of atmospheric nitrate at remote locations. In contrast, the oxygen isotopic composition of nitrate provides original information about the nature and the relative importance of $\mathrm{NO}_{x}$ oxidation pathways, ultimately leading to atmospheric nitrate. In the atmosphere, the ozone molecule possesses a unique isotopic singularity, referred to as the isotope anomaly, originating from mass-independent fractionation during its formation in the atmosphere [Thiemens, 2006; Marcus, 2008, and references therein]. In this study, in agreement with most studies dealing with atmospheric nitrate [Michalski et al., 2003; Alexander et al., 2004; Morin et al., 2007a, 2007b, 2008; McCabe et al., 2007; Savarino et al., 2007; Patris et al., 2007; Kunasek et al., 2008], $\Delta^{17} \mathrm{O}$ is defined as

$$
\Delta^{17} \mathrm{O}=\delta^{17} \mathrm{O}-0.52 \times \delta^{18} \mathrm{O} .
$$

In a linear three isotopes plot (i.e., $\delta^{17} \mathrm{O}$ versus $\delta^{18} \mathrm{O}$ ), $\Delta^{17} \mathrm{O}$ represents the vertical distance of a given sample (or reservoir) to the so-called terrestrial fractionation line, whose equation is $\delta^{17} \mathrm{O}=0.52 \times \delta^{18} \mathrm{O}$, reflecting the dominance of mass-dependent fractionation on the isotopic composition of main terrestrial reservoirs (ocean water, atmospheric water, atmospheric oxygen, bulk silicate Earth [Thiemens, 2006]). In contrast to $\delta^{18} \mathrm{O}, \Delta^{17} \mathrm{O}$ is a conserved variable in the atmosphere; that is, it is not changed by mass-dependent fractionation [Thiemens, 2006; Kendall et al., 2007]. Therefore $\Delta^{17} \mathrm{O}$ of atmospheric species unambiguously traces the influence of ozone in their chemical formation pathways [e.g., Brenninkmeijer et al., 2003; Thiemens, 2006, and references therein]. $\Delta^{17} \mathrm{O}$ of atmospheric nitrate has been used in the recent past to infer variations in the influence of ozone on the photochemical recycling of $\mathrm{NO}_{x}$, and in $\mathrm{NO}_{x}$ oxidation pathways to nitrate in midlatitude coastal and polar environments [Michalski et al., 2003; Alexander et al., 2004; Patris et al., 2007; Morin et al., 2007a, 2007b, 2008; McCabe et al., 2007; Savarino et al., 2007; Kunasek et al., 2008].

[6] We present in this paper a new data set of concentrations and isotopic compositions of atmospheric nitrate samples collected in the MBL of the Atlantic Ocean between $65^{\circ} \mathrm{S}$ (the Weddell Sea) and $79^{\circ} \mathrm{N}$ (Svalbard). Most samples were collected in separate size fractions, providing an opportunity to extract information about the impact of aerosol size and composition on the formation mechanisms of atmospheric nitrate [Finlayson-Pitts and Pitts, 2000; Patris et al., 2007]. On the basis of our new measurements, our goal is threefold: to show how isotopic measurements of nitrate can be used to study atmospheric processes operating on $\mathrm{NO}_{x}$, ozone and related trace gases, to assess the most likely controls over $\delta^{15} \mathrm{~N}$ and $\Delta^{19} \mathrm{O}$ of nitrate, and in this regard to critically review current assumptions, and to identify most pressing needs in this research field. This has important implications in terms of interpreting the message carried by stable isotope ratios of ice-core nitrate [Alexander et al., 2004], in particular its $\delta^{15} \mathrm{~N}$ signature [Freyer et al., 1996; Hastings et al., 2005].

\section{Experiment}

\subsection{Sample Collection}

[7] The samples were obtained during two cruises of the Research Vessel (R/V) Polarstern, in the Weddell Sea area (cruise ANT XXIII/4, from 05 September 2006 to 28 October 2006), and between Cape Town (South Africa) and Bremerhaven (Germany) (cruise ANT XXIII/10, from 13 April 2007 to 03 May 2007). Samples were also collected between 14 February and 27 April 2006 at Ny-Ålesund 


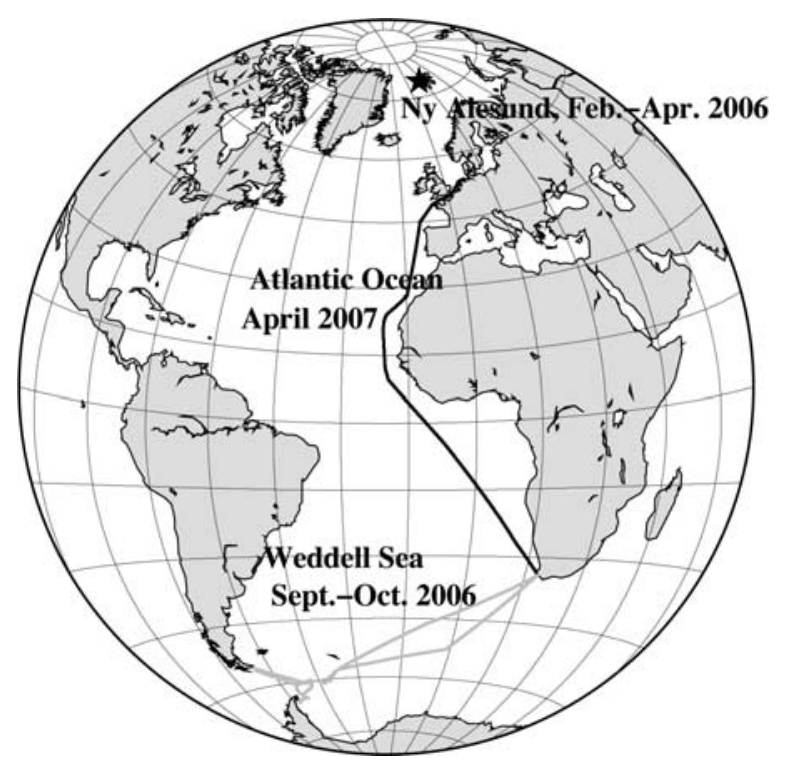

Figure 1. Location and sampling period of the three field campaigns.

$\left(78.7^{\circ} \mathrm{N}, 11.7^{\circ} \mathrm{E}\right)$, on the west coast of Spitsbergen, Svalbard. Figure 1 represents the geographic location of the sampled areas.

[8] Onboard the R/V Polarstern, atmospheric particles (aerosol) were collected on the observation deck (approximately $22 \mathrm{~m}$ above sea level) by means of high-volume sampling (HiVol). At Ny-Ålesund, the air sampler was installed between the so-called Amundsen Mast, located northeast of the main village buildings, and the Kongsfjord coast to the North. The air was pumped at a flow rate of $1.1 \mathrm{~m}^{3} \mathrm{~min}^{-1}$ through a four-stages cascade impactor (Tisch Series 230) loaded with precleaned slotted glass fiber filter $(12.7 \times 17.8 \mathrm{~cm}$, Whatman GF type $)$ and a larger $(20.3 \times$ $25.4 \mathrm{~cm})$ precleaned plain glass fiber filter. This ensures separate collection of particles smaller or larger than approximately $1 \mu \mathrm{m}$ (aerodynamical diameter) [Baker et al., 2007]. In Ny-Ålesund all size fractions were collected on a single glass fiber filter. Sampling times ranged between 1 and 4 days for the three measurement campaigns, depending on the meteorological conditions and the accessibility to the sampling site. For all field campaigns, filters were stored frozen until analysis in the laboratory at LGGE (Grenoble, France).

[9] Soluble species deposited on the filters were dissolved in ultrapure water $(18 \mathrm{M} \Omega \mathrm{cm})$ under clean conditions. All subsequent analyses were performed on nitrate dissolved during this step. The exact nature of the nitrate species trapped on the filters during sampling has been an issue for decades, owing to evaporative loss of ammonium nitrate species and sampling of nitric acid together with particulate nitrate [Schaap et al., 2004]. Prospero and Savoie [1989] have advocated that filters loaded with sea salt should quantitatively collect nitric acid together with particulate nitrate, which should then be the case for these samples collected in the MBL. In addition, the sampling conditions used for this study are similar to previous studies on isotopic ratios of nitrate [Michalski et al., 2003; Savarino et al., 2007; Morin et al., 2007a, 2007b, 2008; Patris et al., 2007], so that comparisons in terms of nitrate atmospheric processing cannot be biased by differences in the filtering materials, although they inevitably depend on the chemical conditions of the atmosphere. Therefore, the analyzed nitrate is referred to as atmospheric nitrate, assumed to be the sum of gas phase nitric acid and particulate nitrate. In the case of sizesegregated measurements, we assume that gas-phase nitric acid was sampled together with submicron aerosol nitrate when the air flow passes through the plain filter, that is the last stage of the impactor.

\subsection{Chemical and Isotopic Analyses}

[10] Nitrate concentrations were determined in filter extracts using a colorimetric method, with a reported uncertainty of approximately $5 \%$ in the range $10-100 \mathrm{ng}$ $\mathrm{g}^{-1}$ [Röthlisberger et al., 2000; Patey et al., 2008]. Atmospheric concentrations were derived by dividing the mass of nitrate recovered on the filters by the total sampled air volume. The contribution of sampling blanks was always found to be negligible.

[11] Nitrogen and oxygen isotopic ratios were measured using the automated denitrifier method, initially developed by Sigman et al. [2001] and Casciotti et al. [2002], and adapted by Kaiser et al. [2007] to the measurement of the comprehensive $\left({ }^{17} \mathrm{O} /{ }^{16} \mathrm{O}\right.$ and $\left.{ }^{18} \mathrm{O} /{ }^{16} \mathrm{O}\right)$ oxygen isotopic composition of nitrate [Morin et al., 2008]. Our system is very similar to the analytical system recently described by Komatsu et al. [2008]. Briefly, this technique uses Pseudomonas Aureofaciens bacteria to convert nitrate into $\mathrm{N}_{2} \mathrm{O}$, which is analyzed for its isotopic composition after being thermally decomposed into $\mathrm{O}_{2}$ and $\mathrm{N}_{2}$ in a gold tube. Below, we briefly describe the analytical procedure used for this study.

[12] Bacteria were grown during a week in a nutrient broth, concentrated by centrifugation and transferred into $20 \mathrm{~mL}$ vials. After completely removing the dissolved $\mathrm{N}_{2} \mathrm{O}$ and the air content of the vials using an He sparge system, nitrate samples were injected into the vials and left overnight for denitrification. $12 \mathrm{~h}$ later, bacteria were then inactivated using $10 \mathrm{M} \mathrm{NaOH}$. Using two needles, the vial was flushed with high-purity $\mathrm{He}$ and gas samples were cryogenically trapped in a stainless-steel sample loop in a liquid nitrogen bath. After 15 min of trapping, the loop was purged with a stream of $\mathrm{He}$ into a gold tube heated to $900^{\circ} \mathrm{C}$, which catalytically converted $\mathrm{N}_{2} \mathrm{O}$ into $\mathrm{N}_{2}$ and $\mathrm{O}_{2}$. This mixture was again cryogenically trapped in a capillary loop internally coated with molecular sieve in a liquid nitrogen bath. After quantitative trapping of all of the $\mathrm{N}_{2} \mathrm{O}$-derived $\mathrm{O}_{2}$ and $\mathrm{N}_{2}$, this mixture was released into a GC column ( $25 \mathrm{~m}$ length, molecular sieve $5 \AA$ ), which is a part of the ThermoFinnigan Gas Bench II interface, to achieve separation of the $\mathrm{O}_{2}$ and $\mathrm{N}_{2}$ peaks. At the end of the column, an open split allowed a small fraction of the flow to be directed into the ionization chamber of a ThermoFinnigan MAT 253 Isotope Ratio Mass Spectrometer. During the data acquisition run, the settings of the mass spectrometer were changed to measure sequentially nitrogen isotope ratios after the oxygen isotope ratios (peak-jumping). We employed a sufficient time lag of $60 \mathrm{~s}$ between the peaks corresponding to the $\mathrm{O}_{2}$ and $\mathrm{N}_{2}$ samples so that possible interferences arising from the tailing of the $\mathrm{O}_{2}$ peak into the $\mathrm{N}_{2}$ peak have no measurable effect on the data. 

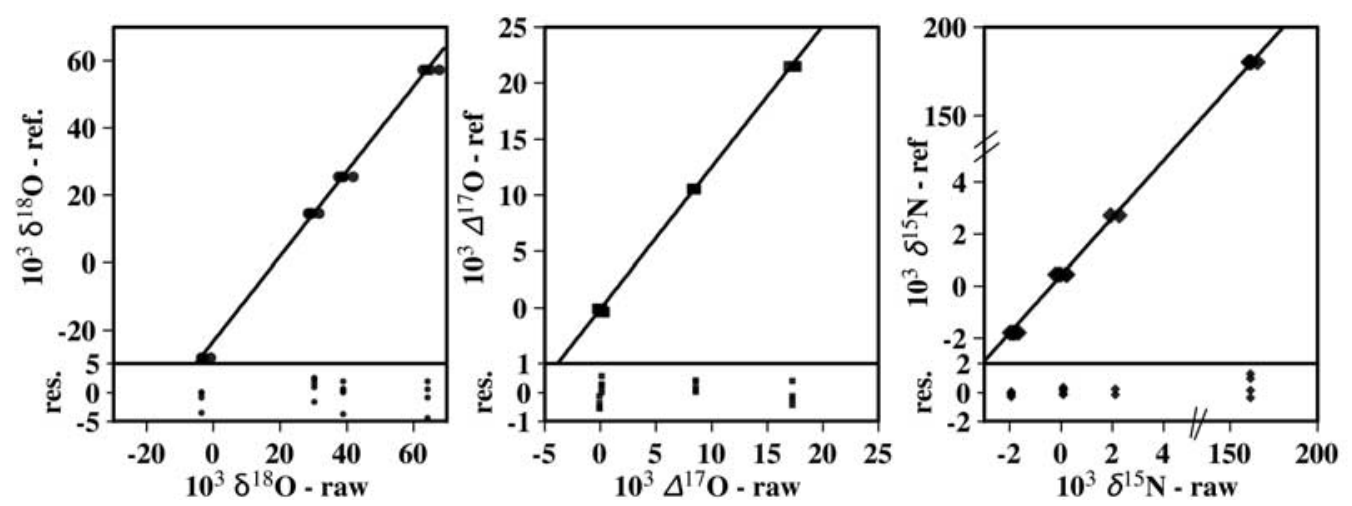

Figure 2. Typical calibration plots for $\delta^{18} \mathrm{O}, \Delta^{17} \mathrm{O}$, and $\delta^{15} \mathrm{~N}$ of atmospheric nitrate (agreed values from Böhlke et al. [2003] versus raw values). Note that two reference materials (USGS 32 and USGS 34) have the same $\Delta^{17} \mathrm{O}\left(=0 \%\right.$ ) so that only three groups of points are visible on the $\Delta^{17} \mathrm{O}$ calibration plot. Note that the linear scale of the $\delta^{15} \mathrm{~N}$ calibration plot is broken between 4 and $150 \%$. Below each calibration plot the residual from the calibration procedure is given. The standard deviation of the residual values gives the total uncertainty of the analytical method.

[13] Isotopic ratios were internally standardized with respect to gas standards in the form of $\mathrm{O}_{2}$ and $\mathrm{N}_{2}$. International nitrate reference materials (USGS 32,34 and 35, and mixtures of USGS 34 and 35 [Bohlke et al., 2003]) were used to calibrate the whole analysis process, including the bacterial stage. Special care was taken to measure the isotopic composition of similar amounts of nitrate fed to the bacteria $\left(100 \mathrm{nmol} \mathrm{NO}_{3}^{-}\right.$). Samples for which the oxygen peak area differed more than $10 \%$ from the peak area corresponding to gases derived from international reference materials were not considered and subsequently remeasured. Figure 2 shows the calibration curves obtained for $\delta^{18} \mathrm{O}, \Delta^{17} \mathrm{O}$ and $\delta^{15} \mathrm{~N}$ (agreed standard values versus raw measured values), for a representative set of analyses. The slopes and the intercepts of the linear correlation between expected and measured values were used to calibrate the isotopic data. This corrected for effects arising from isotopic exchange during the bacterial denitrification reaction [Casciotti et al., 2002; Kaiser et al., 2007] and small blanks from the analytical system, and were specific to a given analytical batch (i.e., similar bacterial cultures and analytical run). The slopes and intercepts of the regression lines are $(1.26,-23.2 \%),(1.26,-0.11 \%)$ and $(1.11$, $0.34 \%$ ) for $\delta^{18} \mathrm{O}, \Delta^{17} \mathrm{O}$ and $\delta^{15} \mathrm{~N}$, respectively, for the examples shown in Figure 2. The correlation coefficients $\left(R^{2}\right)$ for these three regression curves are $0.996,0.998$ and 0.999 , respectively. The overall accuracy of the method is estimated as the reduced standard deviation of the residuals from the linear regression between the measured reference materials and their expected values. For these sets of analyses, the obtained uncertainties values were $2 \%$, $0.5 \%$, and $0.5 \%$, for $\delta^{18} \mathrm{O}, \Delta^{17} \mathrm{O}$ and $\delta^{15} \mathrm{~N}$, respectively.

\subsection{Complementary Data}

[14] Transport pathways and the history of the sampled air masses were analyzed using 5-day back trajectories [Stohl, 1998]. In the case of the ship-borne campaigns, these were computed using the HYSPLIT interface and FNL meteorological fields (R. R. Draxler and G. D. Rolph, HYSPLIT (HYbrid Single-Particle Lagrangian Integrated Trajectory) Model, 2003, available at http://www.arl.noaa. gov/HYSPLIT.php) with an arriving altitude of $50 \mathrm{~m}$ above sea level. The position and time of the arrival of the back trajectories were set to match the geographical and temporal location of the ship in the middle of each sampling period. For Ny-Ålesund, archived output from the Flexpart model [Stohl, 1998] was used (http://tarantula.nilu.no/trajectories/).

[15] Meteorological data from the ship-borne campaigns were provided by the onboard weather station. At NyAllesund, these were measured by the weather station of the AWIPEV station. During the ship-borne campaigns, surface ozone was measured using standard commercial UV-absorption devices. At Ny-Ålesund, the ozone mixing ratios, measured at the Zeppelin station, were provided by NILU.

[16] The sea ice concentration in the Weddell Sea was derived from the Advanced Microwave Scanning Radiometer (AMSR-E) onboard NASA's Earth Observing System (EOS) Aqua satellite using the ARTIST sea ice (ASI) algorithm [Kaleschke et al., 2001; Spreen et al., 2008]. The contact times of air parcels with the sea ice were calculated according to the method of Frieß et al. [2004].

\section{Results}

\subsection{Latitudinal Profiles}

[17] The following section presents latitudinal cross sections of the atmospheric concentration and the isotopic composition of atmospheric nitrate collected in the Atlantic Ocean MBL. See also auxiliary material. ${ }^{1}$ Results are first presented in a bulk form by combining results obtained in the different size fractions. Subsequently, size-segregated measurements are presented. Only bulk measurements can be directly compared with most previous studies carried out on the isotopic composition of atmospheric nitrate [Michalski et al., 2003; Morin et al., 2007a, 2007b, 2008; Savarino et al., 2007].

\subsubsection{Concentrations and Ancillary Measurements}

[18] Figure 3 shows an overview of atmospheric nitrate concentrations and meteorological conditions (represented by mean temperature and cumulated precipitation during the

${ }^{1}$ Auxiliary materials are available at ftp://ftp.agu.org/apend/jd/ 2008JD010696. 


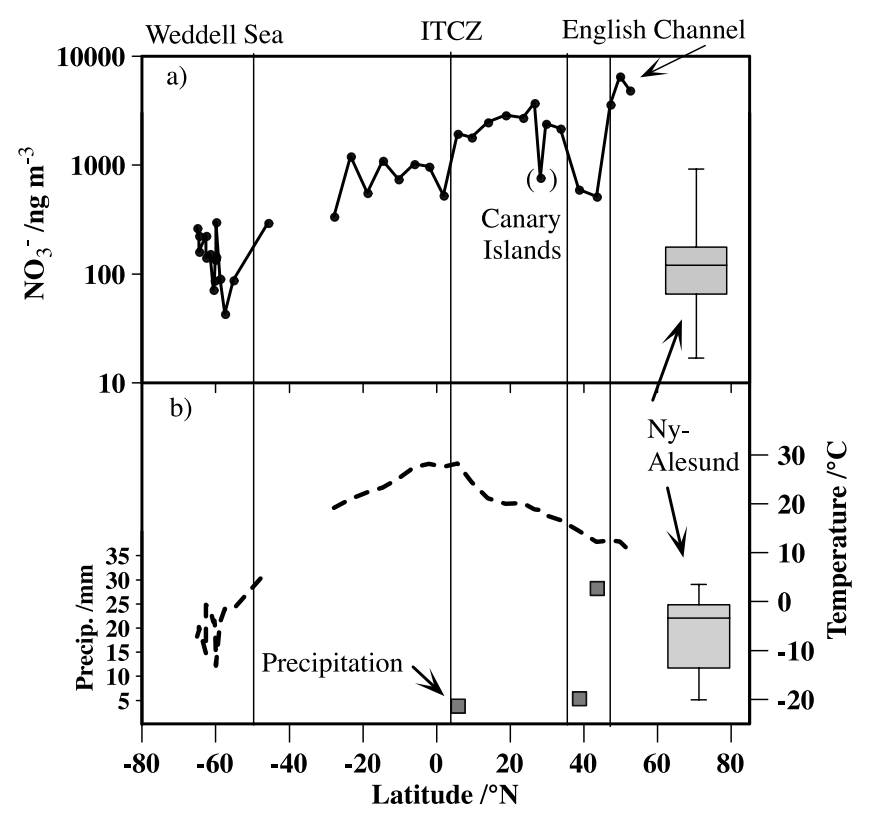

Figure 3. Latitudinal profile of (a) atmospheric nitrate concentrations and (b) air temperature (averaged over each aerosol sampling period). Precipitation events during the ANTXXIII/10 cruise are shown as squares in Figure $3 \mathrm{~b}$. Note that the scale for the nitrate concentration is logarithmic. Vertical lines refer to the boundaries between regions of comparable atmospheric chemical conditions (inferred from nitrate concentrations and ozone mixing ratios), also geographically represented on Figure 4 . The concentration and temperature data obtained in Ny-Ålesund are shown as two whiskers extending to extreme data points and showing the lower quartile, median, and higher quartile.

sampling periods). Nitrate concentrations span a wide range of values from less than $100 \mathrm{ng} \mathrm{m}^{-3}$ in the Weddell Sea to values on the order of $1 \mu \mathrm{g} \mathrm{m}^{-3}$ in the tropical Atlantic, reaching several $\mu \mathrm{g} \mathrm{m}^{-3}$ in the polluted English Channel. These data are consistent with previous measurements carried out on similar latitudinal transects [e.g., Virkkula et al., 2006a]. We note that nitrate levels were significantly reduced in air masses sampled during precipitation events, which is expected from the high solubility of nitrate, making it particularly prone to scavenging by rain and clouds. Except for the polluted conditions in the English Channel, the largest changes in the chemical composition of the atmosphere were associated with the crossing of the intertropical convergence zone (ITCZ, located at $4^{\circ} \mathrm{N}$ during the April 2007 cruise). For example, ozone mixing ratios increased more than twofold upon the northward crossing of the ITCZ (from 20 to $50 \mathrm{nmol} \mathrm{mol}^{-1}$ on average), confirming the impact of this major meteorological boundary on the chemical composition of the atmosphere [Lelieveld et al., 2004]. Figure 4 shows an overview of the back trajectories associated with the sampling during the Atlantic Ocean cruise. It can clearly be seen that air masses south of the ITCZ have a common origin in the central South Atlantic Ocean. North of the ITCZ, all the air masses travel eastward in the North Atlantic Ocean and follow the west coast of Africa before being sampled. West of Portugal, air masses have more direct tracks from the North Atlantic and are affected by the precipitation event described above. Air masses sampled in the English Channel have mixed origins, but the back trajectories suggest a significant impact from continental outflow.

[19] Air masses sampled in the Weddell Sea and the Southern Atlantic Ocean are of several origins (Figure 5) ranging from outflow from the Antarctic continent to air masses involved in the circum-Antarctic (eastward) atmospheric current, and to some air masses from the north, originating from the Falklands region. Atmospheric nitrate concentrations did not appear to depend on the origin of the air masses.

\subsubsection{Bulk Aerosol Isotopic Measurements}

[20] Figure 6 shows the latitudinal profile of the comprehensive isotopic composition of atmospheric nitrate in the Atlantic Ocean MBL during the hemispheric spring.

[21] In nonpolar regions, $\delta^{18} \mathrm{O}\left(\mathrm{NO}_{3}^{-}\right)$was found to vary between 50 and $90 \%$, which is consistent with previous reports for this atmospheric variable [Michalski et al., 2003; Hastings et al., 2003; Kendall et al., 2007, and references

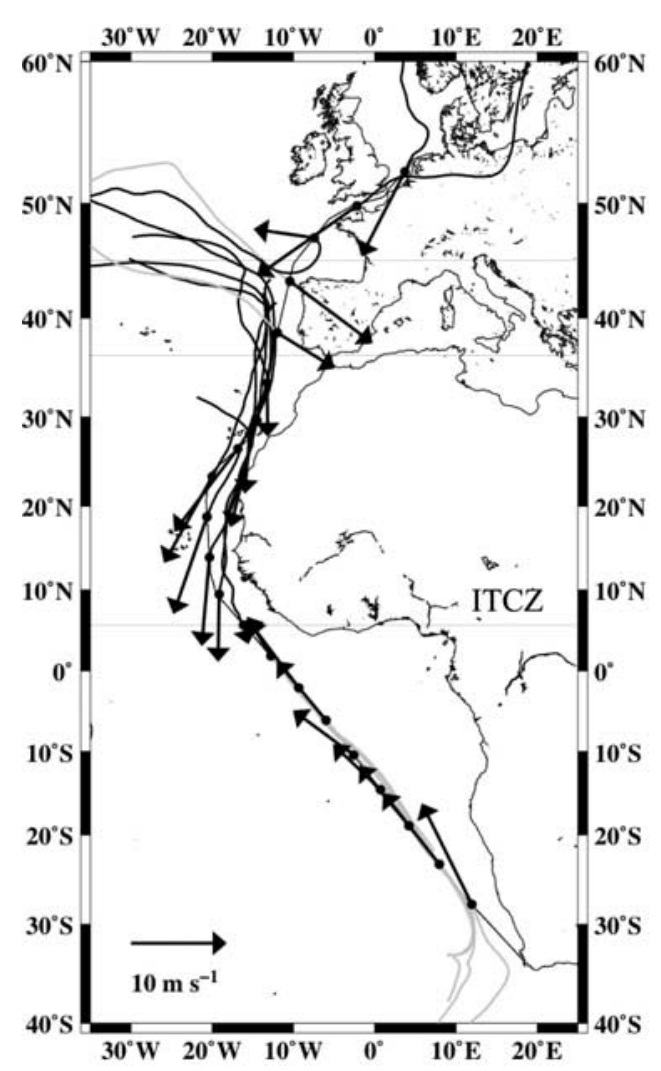

Figure 4. Overview of the back trajectories associated with the sampling over the Atlantic Ocean during the ANTXXIII/10 cruise. Black arrows represent average wind speed and direction measured onboard. Lines represent the 5-day trajectories reaching the middle of each sampling areas. They are classified in four groups on the basis of atmospheric composition criteria (nitrate concentration and ozone mixing ratio). From south to north: grey, south of the ITCZ; black, north of the ITCZ; grey, affected by rain events; black, continental outflow from Europe and English Channel. 


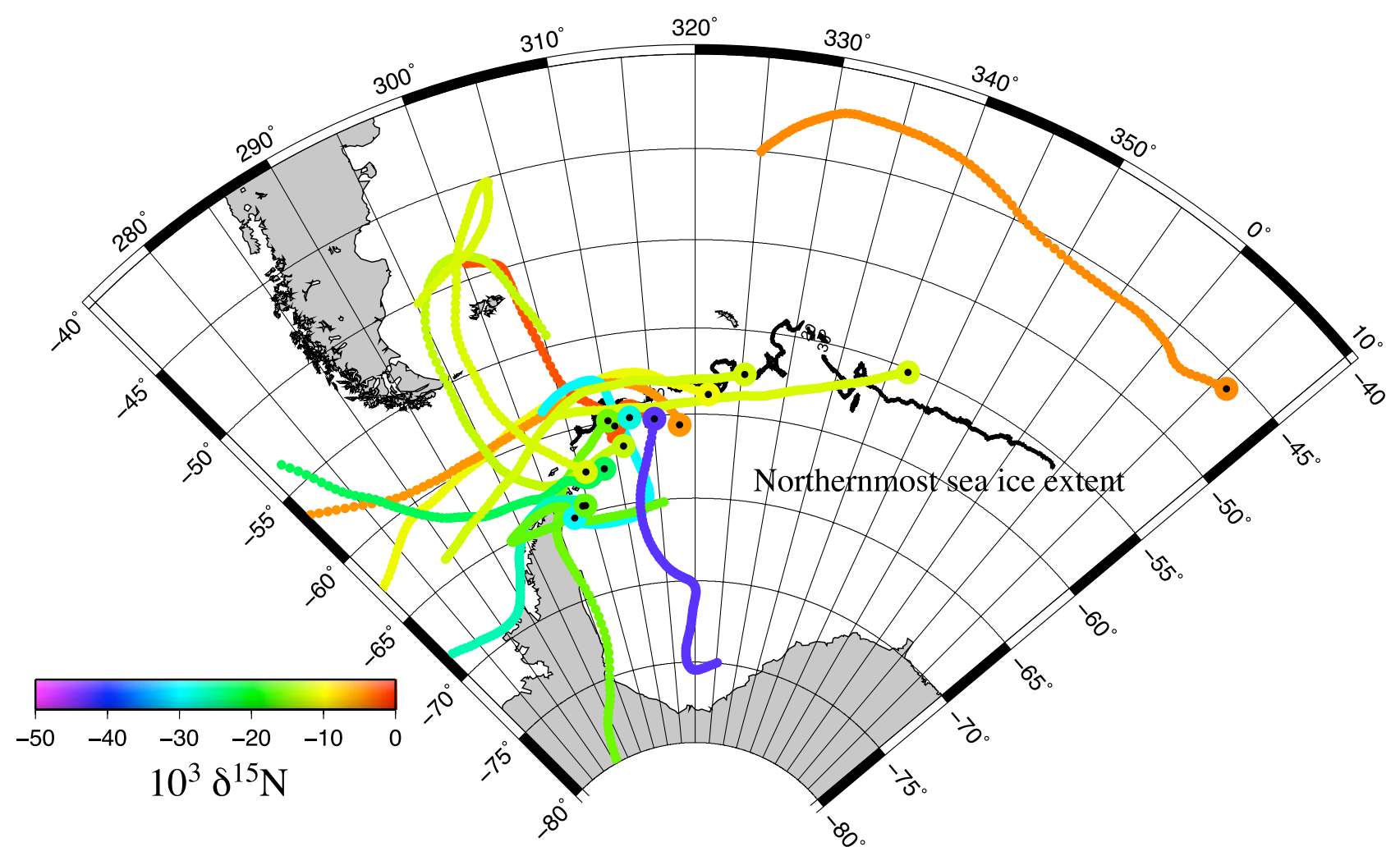

Figure 5. Overview of the back trajectories of the air masses collected in the Weddell Sea in September-October 2006. Each back trajectory is color-coded as a function of $\delta^{15} \mathrm{~N}$ in atmospheric nitrate. The northernmost sea ice extent corresponds to the sea ice edge during the campaign (exhibiting insignificant variations throughout the field campaigns at this geographical scale).

therein]. Polar samples exhibit higher $\delta^{18} \mathrm{O}$ values, which is in agreement with previous measurements carried out in polar regions [Heaton et al., 2004; Savarino et al., 2007; Morin et al., 2007a, 2008]. Both the Weddell Sea and NyÅlesund data sets (averages $(80 \pm 10)$ and $(87 \pm 4) \%$, respectively) are at the high end of the range of atmospheric nitrate $\delta^{18} \mathrm{O}$ observations [Kendall et al., 2007]. $\Delta^{17} \mathrm{O}$ shows a pattern similar to $\delta^{18} \mathrm{O}$; that is, nonpolar areas show values ranging between 24 and 33\%, in the range of previously reported values for midlatitudes [Michalski et al., 2003; Hastings et al., 2003; Patris et al., 2007]. The $\Delta^{17} \mathrm{O}$ data show less scatter that $\delta^{18} \mathrm{O}$. The latitudinal pattern can be summarized by two average values (south and north of the ITCZ). The average values for $\Delta^{17} \mathrm{O}$ are $(26 \pm 2) \%$ (south) and $(29 \pm 2) \%$ (north). $\Delta^{17} \mathrm{O}$ is generally higher in polar regions. The average value of the Ny-Ålesund data set is $35 \% 0\left( \pm 2 \%\right.$ ). Such elevated $\Delta^{17} \mathrm{O}$ values have so far only been observed before in polar regions [Morin et al., 2007a, 2007b, 2008; McCabe et al., 2007; Savarino et al., 2007].

[22] A clear distinction between polar and nonpolar areas can also be found in the $\delta^{15} \mathrm{~N}$ record. Within midlatitudes two groups of data can be distinguished. All of the open ocean $\delta^{15} \mathrm{~N}$ value are negative (ranging from -7.1 to $-1.6 \%$ and averaging $(-4 \pm 2) \%$ from $45^{\circ} \mathrm{S}$ to $\left.45^{\circ} \mathrm{N}\right)$. In contrast, $\delta^{15} \mathrm{~N}$ measurements in air masses influenced by continental pollution outflow (collected between the Gulf of Biscay and the English Channel) are positive, ranging from $0.5 \%$ in the Gulf of Biscay to $5.9 \%$ in the English Channel. This small range of variations (between -7.1 and $5.9 \%$ ) is common for $\delta^{15} \mathrm{~N}$ measurements in the nonpolar $\mathrm{MBL}$ [Freyer, 1991; Yeatman et al., 2001; Baker et al., 2007]. In polar regions, $\delta^{15} \mathrm{~N}$ measurements show strongly negative values ranging from -22.8 to $-6.0 \%$ o (average: $(-15 \pm$ 4)\%o) at Ny-Ålesund from February to April 2006 and from -42.8 to $-1.8 \%$ (average: $(-17 \pm 11) \%$ ) in the Weddell Sea in September and October 2006. Such extremely low $\delta^{15} \mathrm{~N}$ values have only been reported in polar regions in the past in atmospheric nitrate [Freyer et al., 1996; Wagenbach et al., 1998; Savarino et al., 2007; Morin et al., 2008], surface snow in the Arctic [Heaton et al., 2004] and in soils of Antarctic dry valleys [Wada et al., 1981; Michalski et al., 2005].

\subsubsection{Size-Segregated Measurements}

[23] Figure 7 shows the results of the size-resolved measurements. It presents the fraction of nitrate in particles with a diameter of less than $\simeq 1 \mu \mathrm{m}$, and $\delta^{18} \mathrm{O}, \Delta^{17} \mathrm{O}$ and $\delta^{15} \mathrm{~N}$ of nitrate in particles either smaller or larger than $\simeq 1 \mu \mathrm{m}$ as a function of the latitude.

[24] It is observed that nitrate resides mostly in supermicron particles in agreement with studies carried out in different environments [e.g., Hara et al., 1999; Virkkula et al., 2006b]. However, we note that the partitioning of nitrate exhibits a significant latitudinal pattern. In tropical regions, less than $10 \%$ of the nitrate is found in submicron particles. In areas exposed to continental outflow (i.e., in the English Channel and in a few samples collected in the vicinity of continents), this proportion is on the order of $20 \%$. In contrast, in polar areas this proportion varies between 

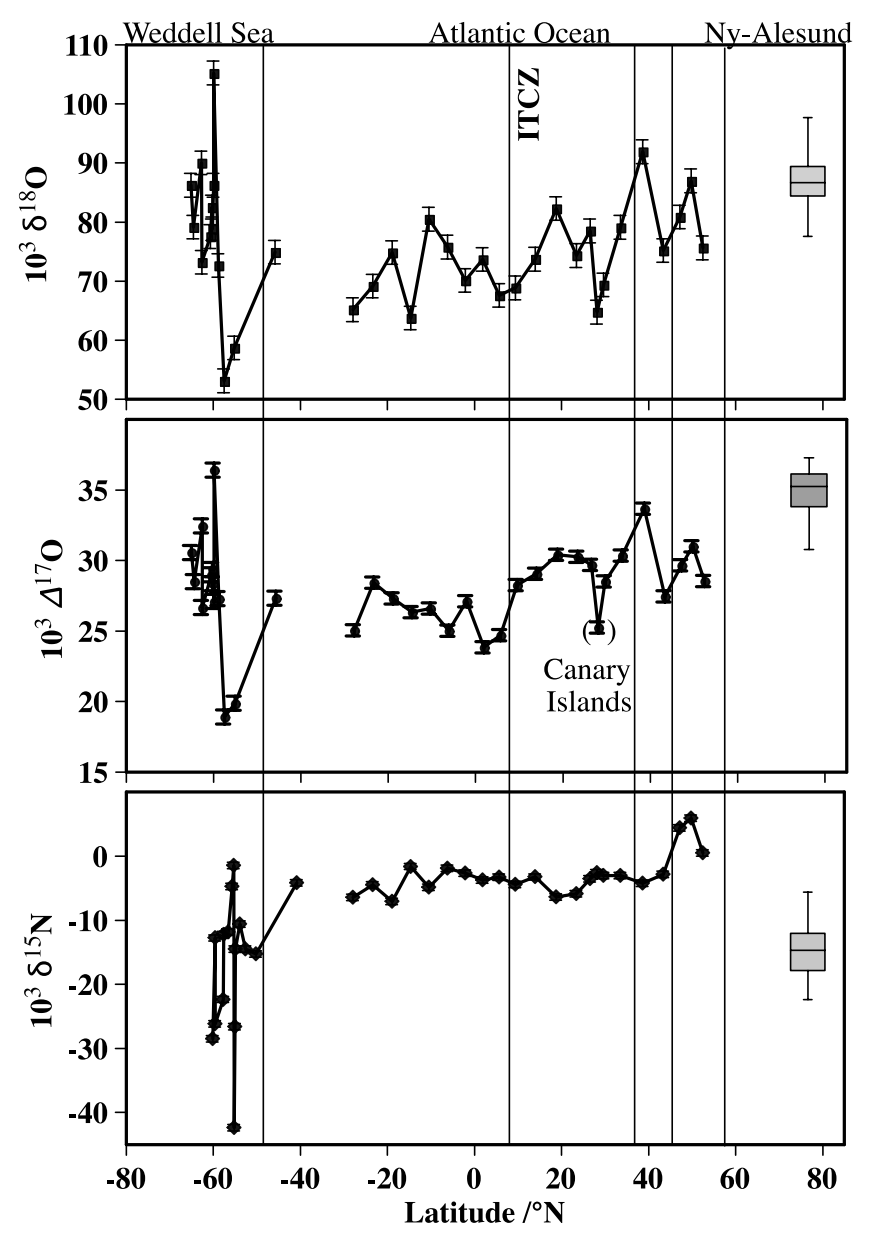

Figure 6. Latitudinal profiles of (top) $\delta^{18} \mathrm{O}$, (middle) $\Delta^{17} \mathrm{O}$, and (bottom) $\delta^{15} \mathrm{~N}$ of atmospheric nitrate in the marine boundary layer. The data obtained in Ny-Alesund are represented as a whisker box extending to extreme data points and showing the lower quartile, median, and higher quartile. Error bars represent the uncertainty of the isotopic measurements.

20 and $55 \%$. Neglecting the few samples influenced by continental outflow as described above, our data reveal an apparent anticorrelation between the proportion of nitrate in submicron particles and air temperature (data not shown), which apparently does not depend on the total concentration of atmospheric nitrate. Similar observation were also made by Virkkula et al. [2006a] over the Atlantic Ocean and in Antarctica. They found the proportion of nitrate residing in submicron particles to be equal to $18 \%$ in polluted regions and on the order of 50\% in the southern Atlantic Ocean and in coastal Antarctica. We hypothesize that this behavior originates from the strong temperature dependence of physicochemical processes operating on nitric acid at the gas/ particle interface, such as the nitric acid-ammonia $\left(\mathrm{NH}_{3}\right)$ ammonium nitrate $\left(\mathrm{NH}_{4} \mathrm{NO}_{3}\right)$ equilibrium [Stelson and Seinfeld, 1982; Bai et al., 1995].

[25] Figure 8 shows the correlation plot between $\delta^{15} \mathrm{~N}$ in the submicron mode and $\delta^{15} \mathrm{~N}$ in the supermicron mode. It shows that most of the measured values are close to a $1: 1$ relationship, although significant deviation also occurs for individual samples. This shows that under these conditions there is no significant difference between $\delta^{15} \mathrm{~N}$ from different size fractions. This appears to contradict previous evidence shown by Freyer [1991], although the cutoff between size fraction was much higher in their study $(3.5 \mu \mathrm{m})$.

[26] Of particular relevance to our study is the case of the samples collected just south of the Canary Islands. On 27 April 2007, the R/V Polarstern, traveling northward, halted for a few hours in Las Palmas (Canary Islands). At that time, the wind came from the North, implying that the ship was downwind of Las Palmas before reaching the port, and upwind after leaving it. In contrast to the $\delta^{15} \mathrm{~N}$ of nitrate sampled over the open Atlantic Ocean, $\delta^{15} \mathrm{~N}$ of nitrate in the submicron mode sampled the day before reaching Las Palmas exhibits a higher value of $4.4 \%$. The supermicron nitrate $\delta^{15} \mathrm{~N}$ was similar to measurements carried out on

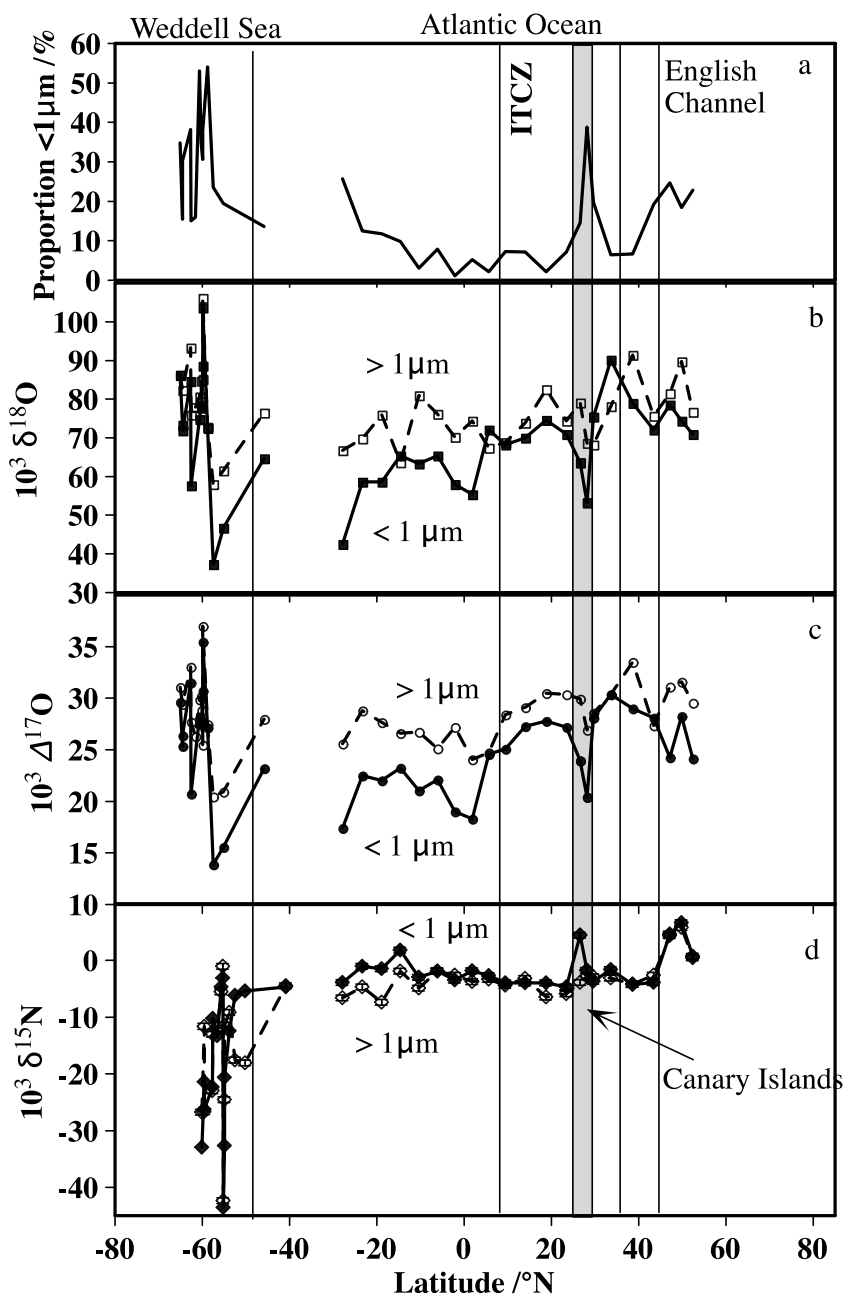

Figure 7. Latitudinal profiles of (a) the fraction of nitrate residing in the submicron mode and the size-resolved comprehensive isotopic composition of atmospheric nitrate: (b) $\delta^{18} \mathrm{O}$, (c) $\Delta^{17} \mathrm{O}$, and (d) $\delta^{15} \mathrm{~N}$. Data for the supermicron (submicron) mode are indicated with open (solid) symbols. The shaded periods refer to the area influenced by the plume from the Canary Islands (Las Palmas) (see text). Uncertainties are the same as on Figure 6 and have not been included in the present graph for clarity. 


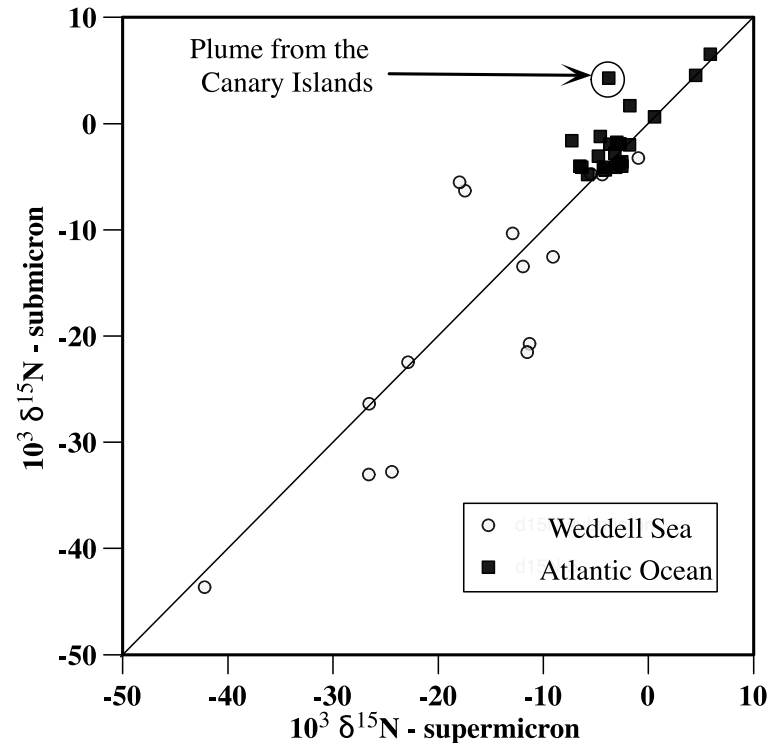

Figure 8. The $\delta^{15} \mathrm{~N}$ in the submicron mode, as a function of $\delta^{15} \mathrm{~N}$ in the supermicron mode, from the two campaigns in the Weddell Sea (open circles) and the Atlantic Ocean (solid squares), respectively. The size of the error bars is similar to that of the symbols used.

previous and subsequent days $(-3.9 \%)$. Measurements carried out in the port of Las Palmas itself show no deviation from the regional pattern discussed above $(-1.8$ and $-2.8 \%$ in the submicron and supermicron size fractions, respectively). This strongly suggests that the exceptionally high $\delta^{15} \mathrm{~N}$ measured downwind of the Canary Islands was the signature of a pollution plume originating from these islands. We note that this signature is only captured in the submicron size fraction, in samples collected a few hours of atmospheric transport downwind the Canary Islands.

[27] The oxygen isotopic composition of nitrate exhibits significantly different patterns in the different size fractions (Figure 7). $\Delta \Delta^{17} \mathrm{O}$ is always higher in the supermicron mode than in the submicron mode. The average difference is equal to $(6 \pm 2) \%$ south of the ITCZ, and is smaller north of the ITCZ (on average $(3 \pm 3) \%$ ). This latter figure is in agreement with the observations of Patris et al. [2007] in the MBL in northern California, who reported a difference on the order of $1.5 \%$ between fine and coarse aerosol nitrate. However, the direct comparison remains limited since the diameter cutoff between the two modes was higher in the study of Patris et al. [2007], because they combined the lowermost impactor plate with the final plain filter in order to obtain enough material to perform the isotopic analysis. This may have smoothed the $\Delta^{17} \mathrm{O}$ gradient between the size fractions leading to lower apparent differences than the results presented here. In terms of $\delta^{18} \mathrm{O}$, the situation is also contrasted between the regions north and south of the ITCZ. South of the ITCZ, supermicron nitrate $\delta^{18} \mathrm{O}$ tends to be higher than in the submicron mode (average difference: $(14 \pm 7) \%$ ). North of the ITCZ, the difference is not significant, showing both positive and negative values (Figure 7).

\subsection{Time Series of the Ny-Ålesund Data}

[28] Figure 9 presents the measured time series of atmospheric concentrations and the isotopic composition of nitrate at Ny-Ålesund. The measurement campaign encompassed the whole transition from complete darkness to permanent sunlight. As outlined by Stohl et al. [2007], the winter and spring 2006 were unusually warm at Ny-Ålesund. Mean monthly temperatures for January to April were on average $10.7,3.8,1.4$ and $10.3 \mathrm{~K}$, respectively, above monthly mean values recorded since 1969. The Kongsfjord remained ice-free for the whole measurement campaign, which has already occurred in the recent past (e.g., spring 2004, 2006 and 2007). In contrast to "normal" Arctic spring conditions, during which several ozone depletion events (ODEs) are typically observed [Solberg et al., 1996; Tarasick and Bottenheim, 2002; Simpson et al., 2007, and references therein], the ozone mixing ratios remained stable (40 and $50 \mathrm{nmol} \mathrm{mol}^{-1}$ ) and dropped below $10 \mathrm{nmol} \mathrm{mol}^{-1}$ only for less than 1 day (20 March) (Figure 9). On 26 April,

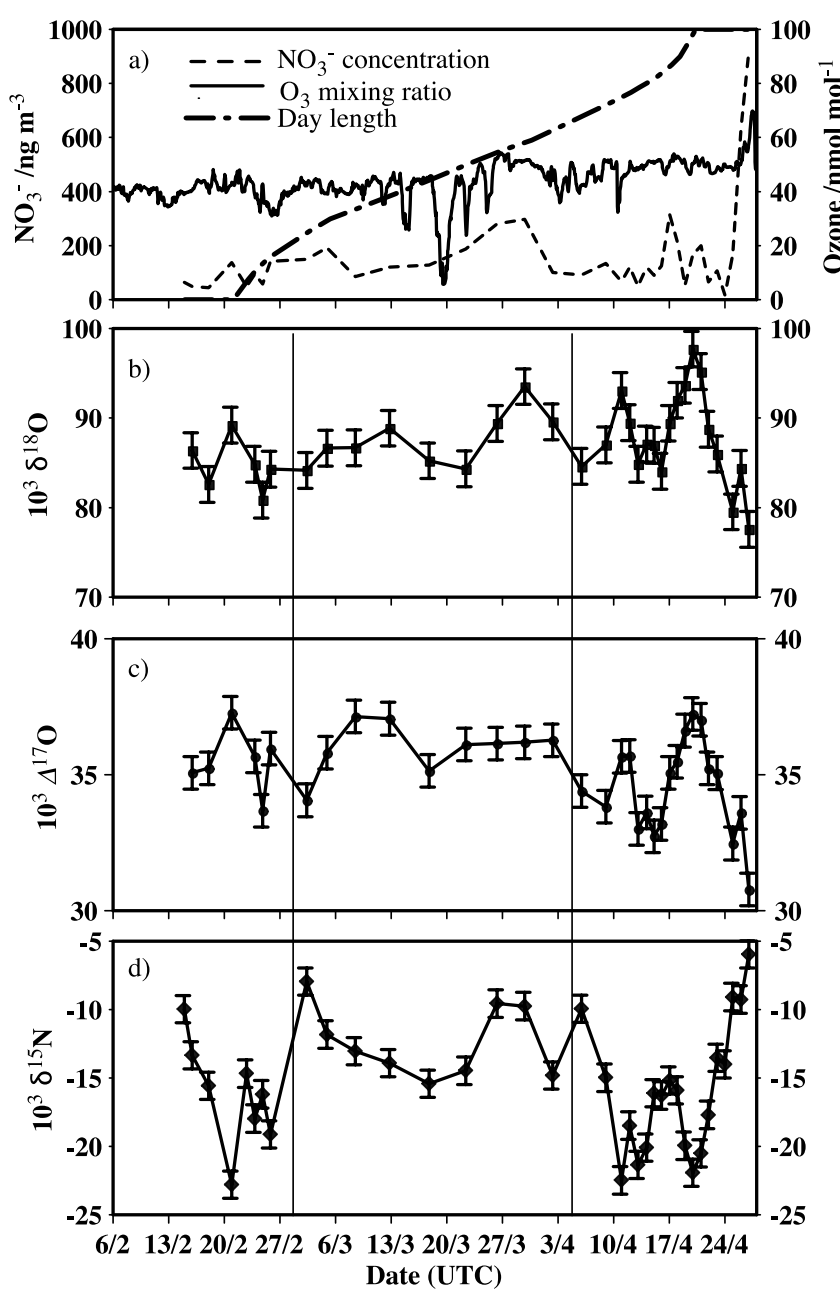

Figure 9. (a) Time series of ozone mixing ratio, daylength (from 0 to $24 \mathrm{~h}$ ) and nitrate concentration at Ny-Ålesund, from February to April 2006. (b, c, and d) Also displayed are the comprehensive isotopic composition of nitrate during the same time interval. Sampling resolution ranges from 1 day (in February and late April) to 3 days in between (separated by vertical lines). 


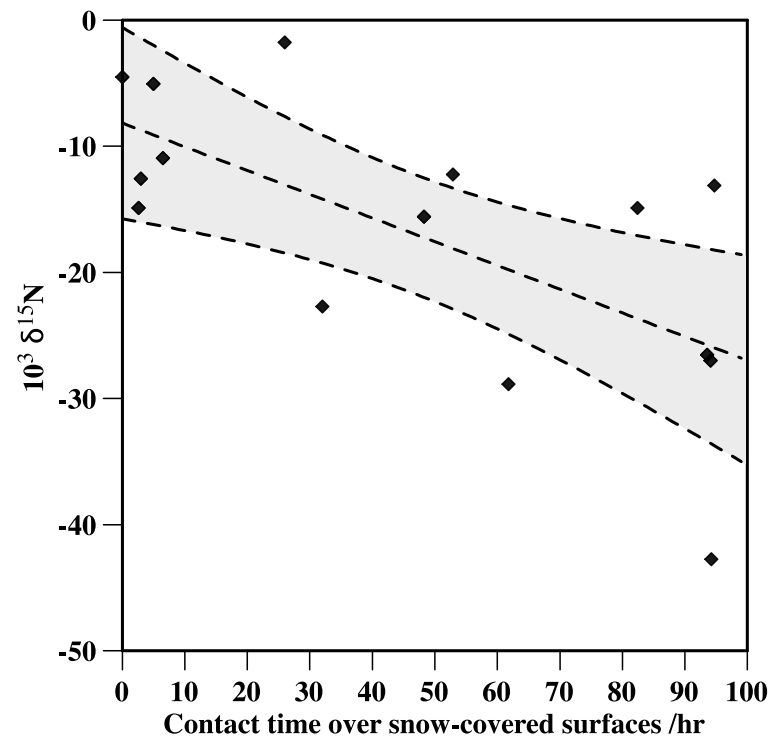

Figure 10. Relationship between bulk atmospheric $\delta^{15} \mathrm{~N}\left(\mathrm{NO}_{3}{ }^{-}\right)$in the Weddell Sea and the calculated contact time of the air parcels with snow-covered areas. The analytical uncertainty $(0.5)$ is smaller than the symbol representing each data point. Also shown (dashed lines) are the linear regression line of the data and the $95 \%$ confidence interval.

ozone levels exhibited a large increase to values as high as $70 \mathrm{nmol} \mathrm{mol}{ }^{-1}$. Such high levels are quite unusual for the Arctic and have been attributed by Stohl et al. [2007] to long-range transport of an agricultural fire plume with record-high levels of ozone. Figure 9 suggests that this plume also transported elevated levels of atmospheric nitrate.

[29] As described in section 3.1.2, the ranges of variations of $\delta^{18} \mathrm{O}, \Delta^{17} \mathrm{O}$ and $\delta^{15} \mathrm{~N}$ are in agreement with previous measurements carried out in the atmosphere, in particular in the Arctic [Heaton et al., 2004; Morin et al., 2007a, 2007b, 2008]. Both $\delta^{18} \mathrm{O}$ and $\Delta^{17} \mathrm{O}$ show a significant variability throughout the measurement campaign, which is apparently related neither to atmospheric chemical properties (i.e., no link with either ozone levels or atmospheric nitrate concentrations) or physical conditions such as the air temperature at $\mathrm{Ny}$-Allesund. The $\delta^{15} \mathrm{~N}$ was also highly variable on a dayto-day basis. In what follows, we focus on the February and April periods, when the sampling resolution was one day. The sampling carried out in between allows to connect these two high time-resolution data sets. On the basis of these two periods of interest, our data show a clear anticorrelation between $\delta^{15} \mathrm{~N}$ and $\Delta^{17} \mathrm{O}$. Periods of lowest $\delta^{15} \mathrm{~N}$ (reaching $-24 \%$ on three occasions, on 21 February, 10 April and 20 April) are systematically associated with highest $\Delta^{17} \mathrm{O}$ values (37.3, 35.7 and 37.2\%o, respectively).

[30] A complementary analysis, based on a compilation of back trajectories reaching Ny-Alesund during each sampling period (see section 2.3), reveals that air masses having low $\delta^{15} \mathrm{~N}$ predominantly originate from the Arctic basin in general, which is covered by snow during this part of the year. Higher $\delta^{15} \mathrm{~N}(>-10 \%)$ are generally associated with rapid transport from midlatitudes, the extreme case being the agricultural fire plume sampled at the end of the sampling campaign in 25 April [Stohl et al., 2007] showing the highest $\delta^{15} \mathrm{~N}$ value $(-6.0 \%)$.

\subsection{Air Mass History $/ \delta^{15} \mathrm{~N}$ Analysis Over the Weddell Sea}

[31] As described above, during this short measurement period of less than 2 months, $\delta^{15} \mathrm{~N}$ values ranged from -1 to $-43 \%$ (Figure 6 ), with a maximum variation of $30 \%$ between two consecutive samples (on average $(10 \pm 10) \%$ ). The reported large range of $\delta^{15} \mathrm{~N}$ values is compatible with previous measurements carried out in coastal Antarctica [Freyer et al., 1996; Wagenbach et al., 1998; Savarino et al., 2007]. However, such a large variability within such a limited time interval has never been reported before. Figure 5 represents the $\delta^{15} \mathrm{~N}$ data obtained on the Weddell Sea samples together with the back trajectories for each sample. The map also indicates the sea ice edge, which showed insignificant variations throughout the measurement period. Both sea ice-covered regions and the Antarctic continent are referred to as snow-covered for the entire duration of the sampling period. For each sample (the mean sampling location being represented as a black dot) an air mass back trajectory typical of the sampling conditions is shown using a color coding representing the $\delta^{15} \mathrm{~N}$ of the sample. This allows to derive a visual correlation between $\delta^{15} \mathrm{~N}\left(\mathrm{NO}_{3}^{-}\right)$and the corresponding air mass trajectory. Highest $\delta^{15} \mathrm{~N}$ values correspond to trajectories not crossing snow-covered areas, and lowest $\delta^{15} \mathrm{~N}$ values correspond to trajectories originating from the Antarctic region and/or crossing snow-covered areas. To quantify this apparent link, Figure 10 shows the relationship between $\delta^{15} \mathrm{~N}\left(\mathrm{NO}_{3}^{-}\right)$and the time of contact of the air mass with snow-covered areas. In agreement with the visual correlation inferred from Figure 5, an anticorrelation is found between $\delta^{15} \mathrm{~N}\left(\mathrm{NO}_{3}^{-}\right)$ and the contact time of the associated air masses with snowcovered areas. As may expected for such an heterogeneous data set (different aerosol sampling time, meteorological conditions, incoming shortwave radiation, etc.), the correlation coefficient of $R^{2}=0.43(n=15)$ reflects a weak but significant anticorrelation between the two variables.

\section{Interpretation of the Nitrogen Isotopic Ratios of Nitrate}

[32] Atmospheric nitrate originates from the oxidation of $\mathrm{NO}_{2}$ [Finlayson-Pitts and Pitts, 2000]. Therefore, variations in $\delta^{15} \mathrm{~N}\left(\mathrm{NO}_{3}^{-}\right)$can either result from variations of $\delta^{15} \mathrm{~N}\left(\mathrm{NO}_{2}\right)$ (due to variations in $\delta^{15} \mathrm{~N}\left(\mathrm{NO}_{x}\right)$ and/or ${ }^{15} \mathrm{~N}$ partitioning within $\mathrm{NO}_{x}$ ), from isotopic fractionation arising during the conversion of $\mathrm{NO}_{2}$ to nitrate or during transport of atmospheric nitrate itself. Deciphering the exact and precise reasons governing the $\delta^{15} \mathrm{~N}$ in atmospheric nitrate is beyond the scope of this study, given the paucity in $\delta^{15} \mathrm{~N}$ data for $\mathrm{NO}_{x}$ and atmospheric nitrate available to date, and the poor knowledge of fractionation constants $(\varepsilon$ values [Criss, 1999]) associated with the chemical reactions involved. Nevertheless, using our $\delta^{15} \mathrm{~N}$ measurements carried out on atmospheric nitrate in the MBL, we provide the basis for their interpretation and relate them to $\delta^{15} \mathrm{~N}$ of the nitrate sources and the effect of physicochemical transformations in the atmosphere. 


\subsection{Interpretation of $\delta^{\mathbf{1 5}} \mathrm{N}$ Data in Nonpolar Regions}

[33] The $\delta^{15} \mathrm{~N}$ data of atmospheric nitrate over the Atlantic Ocean in nonpolar regions can be separated in two groups according to the sampling location. We distinguish here low-latitude $\left(45^{\circ} \mathrm{S}\right.$ to $\left.45^{\circ} \mathrm{N}\right)$ and midlatitude (European influenced) regions, on the basis of significantly different $\delta^{15} \mathrm{~N}$ values measured in atmospheric nitrate (see Figure 6). 4.1.1. Low-Latitude Regions

[34] We first focus on the values for $\delta^{15} \mathrm{~N}$ in atmospheric nitrate recorded between $45^{\circ} \mathrm{S}$ and $45^{\circ} \mathrm{N}$. The measured values were generally negative (ranging from -7.1 to $-1.6 \%$ and averaging $(-4 \pm 2) \%$ ). These data are in good agreement with the values reported by Baker et al. [2007] from the low-latitude Atlantic Ocean in October and November 2002, ranging between -11 and $2.8 \%$ and averaging $(-3 \pm 3) \%$. Although the $\delta^{15} \mathrm{~N}$ of atmospheric nitrate sampled in this area exhibits a large variability (approximately 3\%), observations from these two campaigns suggest that mostly negative $\delta^{15} \mathrm{~N}$ values are encountered in this region, on the order of -3 to $-4 \%$ on average. The stated variability of $\delta^{15} \mathrm{~N}$ values includes the effect of isotopic effect(s) related to transport of atmospheric nitrate, owing to the short (hours to days) lifetime of $\mathrm{NO}_{x}$ toward oxidation to atmospheric nitrate [Finlayson-Pitts and Pitts, 2000] and the large geographical coverage of our sampling. It is thus assumed that the isotopic composition of nitrate sampled in this region is representative of a region more rather that of a point. The isotopic effect(s) associated to transport are discussed below (see section 4.1.3).

[35] Combining a recent evaluation of $\mathrm{NO}_{x}$ sources at the global scale [van der A et al., 2008, and references therein] and the origin of the air masses sampled in this regions (see Figure 4) reveals that the nitrate sampled in this region derives from the conversion of $\mathrm{NO}_{x}$ originating from a combination of natural sources such as lightning, biomass burning and soil emissions. These $\mathrm{NO}_{x}$ sources have different $\delta^{15} \mathrm{~N}$ signatures. The $\delta^{15} \mathrm{~N}$ of $\mathrm{NO}_{x}$ produced by lightning processes [Schumann and Huntrieser, 2007] is assumed to be zero [Hoering, 1957] because of the very high temperatures prevailing during this process, most likely annihilating any isotopic fractionation. The isotopic signature of $\mathrm{NO}_{x}$ produced through biomass burning has not been assessed, because it depends on the isotopic composition of the starting material (e.g., wood) and the temperature of the combustion (see section 4.1.2). The $\delta^{15} \mathrm{~N}$ of NO originating from soil emissions [Davidson and Kingerlee, 1997] has recently been suggested, on the basis of laboratory experiments, to be extremely negative with values ranging between -20 and $-50 \%$ [ $L i$ and Wang, 2008]. However, these first results, obtained on fertilizer-amended experimental soil solutions, are not necessarily representative of all $\mathrm{NO}_{x}$ soil emissions, especially of natural soils. Nonetheless, they still provide an indication of the sign and the range of the $\delta^{15} \mathrm{~N}$ of $\mathrm{NO}_{x}$ emitted by soils, which is consistent with the predictions of Freyer et al. [1993].

[36] According to Freyer et al. [1993], under conditions where $\mathrm{NO}_{x}$ levels are much lower than ozone levels (which is the case in the region of interest [Lelieveld et al., 2004; van der $A$ et al., 2008]), $\delta^{15} \mathrm{~N}\left(\mathrm{NO}_{2}\right)$ is equivalent to $\delta^{15} \mathrm{~N}\left(\mathrm{NO}_{x}\right)$. At night all $\mathrm{NO}_{x}$ is converted to $\mathrm{NO}_{2}$ owing to the titration of NO by ozone. During the day, fast photochemical recycling between $\mathrm{NO}_{x}$ and ozone [Leighton,
1961; Crutzen, 1970] is hypothesized not to induce any differential partitionment of ${ }^{15} \mathrm{~N}$ within $\mathrm{NO}_{x}$ [Freyer et al., 1993].

[37] On the basis of standard reduced-mass calculations following the formalism of Bigeleisen [1952], Freyer [1991] proposed that nitrate production through the $\mathrm{OH}+\mathrm{NO}_{2}$ pathway should induce a fractionation of approximately $-3 \%$, leading to a $\delta^{15} \mathrm{~N}$ in nitrate produced through this pathway about $3 \%$ lower than $\delta^{15} \mathrm{~N}\left(\mathrm{NO}_{2}\right)$. The same author suggested that formation of nitrate through the hydrolysis of $\mathrm{N}_{2} \mathrm{O}_{5}$ would lead to a positive (unquantified) fractionation [Freyer, 1991]. There is very limited evidence to support such assumptions, and the isotopic effects associated with the $\mathrm{NO}_{x}$ to nitrate conversion reactions are generally assumed to be negligible [e.g., Hastings et al., 2003]. Our combined observations of oxygen and nitrogen isotopic ratios of nitrate in different size fractions strongly support this (see section 5.3).

[38] We conclude from this analysis that negative $\delta^{15} \mathrm{~N}$ values in atmospheric nitrate sampled in low-latitude regions not under the direct influence of anthropogenic emissions of $\mathrm{NO}_{x}$ are broadly representative of a combination of the natural $\mathrm{NO}_{x}$ sources (lightning, biomass burning and soil emissions) operating at this geographical scale. Within an average mean value of $-4 \%$ in our data set, on the basis of samples collected in April 2007, deviations from the mean most likely originate from differences in proportions of $\mathrm{NO}_{x}$ sources and the effect of transport processes of nitrate. We elaborate on transport effects in section 4.1.3.

\subsubsection{European Influenced Areas}

[39] Atmospheric nitrate samples collected North of $45^{\circ} \mathrm{N}$ (i.e., Gulf of Biscay and English Channel), show positive $\delta^{15} \mathrm{~N}$, ranging from $0.5 \%$ in the Gulf of Biscay to $5.9 \%$ in the English Channel. A comparison of the back trajectories of the air masses sampled in this region with the global distribution of $\mathrm{NO}_{x}$ sources [van der A et al., 2008] shows that the main source of $\mathrm{NO}_{x}$ in this region is anthropogenic.

[40] From a purely phenomenological perspective, our results (combined with the observation from the outflow of the Canary Islands; see section 5.3) lead to the simple observation that nitrate derived from anthropogenic sources carries a significantly higher $\delta^{15} \mathrm{~N}$ value than nitrate derived from natural sources (see above and Figure 6). This is consistent with the measurements carried out by Freyer [1991] in Jülich, Germany and Yeatman et al. [2001] in polluted conditions in the United Kingdom. Both studies report positive $\delta^{15} \mathrm{~N}$ values in atmospheric nitrate under polluted conditions, featuring in addition marked seasonal variations [Freyer, 1991; Yeatman et al., 2001] that were obviously not captured by our transect measurements.

[41] In general, $\mathrm{NO}_{x}$ emitted by anthropogenic sources can be separated in two classes, i.e., high-temperature conversion of atmospheric $\mathrm{N}_{2}$ and $\mathrm{O}_{2}$ to $\mathrm{NO}_{x}$ ("thermal" $\mathrm{NO}_{x}$ ) and the oxidation of nitrogen initially contained in the fuel ("fuel" $\mathrm{NO}_{x}$ ) [Snape et al., 2003; Widory, 2007]. The $\delta^{15} \mathrm{~N}$ of thermal $\mathrm{NO}_{x}$ exhibits negative values. Snape et al. [2003] measured values on the order of $(-6.2 \pm 0.9) \%$ from the exhaust of an industrial plant. This falls in the range of -13 to $-2 \%$ derived by Heaton [1990] from vehicle emissions under different loads. In contrast, $\delta^{15} \mathrm{~N}$ of fuel $\mathrm{NO}_{x}$ generally shows positive values. In this case, Snape et 
al. [2003] determined values on the order of $(15 \pm 2) \%$ from coal combustion. While Heaton [1990] observed a much broader range of 6 to $13 \%$ o for the same source, the values are in all cases positive, and should be weakly dependent on the $\delta^{15} \mathrm{~N}$ of nitrogen in coal, which varies between 0 and 2\%o [Heaton, 1990; Snape et al., 2003]. Industrial production of $\mathrm{NO}_{x}$ proceeds through both of the above mentioned processes, in proportions depending upon the chemical composition of the fuel, the richness (i.e., the rate of mixing of fuel and molecular oxygen) and the temperature of the combustion, which in turn dictate the $\delta^{15} \mathrm{~N}$ of the $\mathrm{NO}_{x}$ produced. Coal-fired energy production units most likely induce positive $\delta^{15} \mathrm{~N}$ in the generated $\mathrm{NO}_{x}$ [Elliott et al., 2007]. The $\delta^{15} \mathrm{~N}$ signature of road-traffic $\mathrm{NO}_{x}$ depends on the relative proportion of thermal and fuel $\mathrm{NO}_{x}$ produced in car and truck engines. Although conflicting results have been reported [Moore, 1977], there are good indications that $\delta^{15} \mathrm{~N}$ of traffic $\mathrm{NO}_{x}$ is positive, on the order of 5\%o [Ammann et al., 1999; Saurer et al., 2004].

[42] When $\mathrm{NO}_{x}$ levels are comparable to ozone levels, Freyer et al. [1993] showed that isotopic exchange occurs between $\mathrm{NO}$ and $\mathrm{NO}_{2}$, leading to differences between $\delta^{15} \mathrm{~N}\left(\mathrm{NO}_{2}\right)$ and $\delta^{15} \mathrm{~N}\left(\mathrm{NO}_{x}\right)$. Isotopic exchange proceeds mainly at night through the formation of $\mathrm{N}_{2} \mathrm{O}_{3}$. The isotopic fractionation associated with the dissociation of $\mathrm{N}_{2} \mathrm{O}_{3}$ back to $\mathrm{NO}$ and $\mathrm{NO}_{2}$ leads to higher $\delta^{15} \mathrm{~N}$ in $\mathrm{NO}_{2}$ than in $\mathrm{NO}$. During the day, photochemical recycling between $\mathrm{NO}_{x}$ and ozone counteracts this fractionation effect (see above and Freyer et al. [1993]). Thus, in addition to potential seasonal changes in $\delta^{15}\left(\mathrm{NO}_{x}\right)$ due to variations in the proportions between $\mathrm{NO}_{x}$ sources, $\delta^{15}\left(\mathrm{NO}_{2}\right)$ exhibits strong seasonal changes due to the isotopic exchange reaction [Freyer et al., 1993], which maximizes in winter owing to longer nights and reduced photochemical activity during the day. According to Freyer et al. [1993], in polluted environments, seasonal variations of $\delta^{15} \mathrm{~N}$ in atmospheric nitrate directly originate from seasonal changes of $\delta^{15} \mathrm{~N}\left(\mathrm{NO}_{2}\right)$.

\subsubsection{Isotopic Effect of the Transport of Atmospheric} Nitrate $\delta^{15} \mathbf{N}$

[43] One key process able to partially remove nitrate from an air mass during transport is wet deposition, i.e., the washout of nitrate by the rain. Assessing its impact necessitates understanding the isotopic effect of the uptake of atmospheric nitrate in rain droplets, which in addition should enable the comparison of $\delta^{15} \mathrm{~N}$ data from atmospheric and rainwater nitrate. Relying on field measurements requires collocated measurements of $\delta^{15} \mathrm{~N}$ of both atmospheric and rainwater nitrate. On the basis of measurements carried out in Jülich, Freyer [1991] showed that $\delta^{15} \mathrm{~N}$ of atmospheric nitrate is higher than rainwater nitrate by $(9 \pm$ 2)\%o, relatively constant throughout the year. The data of Baker et al. [2007] are in strong disagreement with this observation. The two rain episodes analyzed for $\delta^{15} \mathrm{~N}\left(\mathrm{NO}_{3}^{-}\right)$ show $\delta^{15} \mathrm{~N}$ in atmospheric nitrate lower by 6.4 to $9.6 \%$ than rainwater nitrate [Baker et al., 2007; A. R. Baker, personal communication, 2008]. Such a discrepancy renders extremely difficult any quantitative comparison between nitrogen isotopic data based on rainwater samples [Hastings et al., 2003; Elliott et al., 2007] and on atmospheric nitrate [Baker et al., 2007; Savarino et al., 2007; Morin et al., 2008].
[44] On the basis of the results of Freyer [1991], it has been argued that wet deposition of nitrate during transport should lead to increasing $\delta^{15} \mathrm{~N}$ values in the remaining atmospheric nitrate. Therefore gradual removal of atmospheric nitrate by wet deposition should lead to an isotopic enrichment of atmospheric nitrate in terms of $\delta^{15} \mathrm{~N}$, thereby ruling out transport as a likely cause for depleted $\delta^{15} \mathrm{~N}$ values in nitrate of atmospheric origin remote regions such as in Antarctica [Wada et al., 1981; Michalski et al., 2005] and in the Arctic atmosphere [Morin et al., 2008] and snow [Hastings et al., 2004; Heaton et al., 2004]. The evidence from the data presented by Baker et al. [2007] cast doubts on this implication of the Freyer [1991] data, suggesting that the links between $\delta^{15} \mathrm{~N}$ in rainwater and atmospheric nitrate are not unequivocal, and that wet deposition could in some circumstances lead to a gradual depletion of $\delta^{15} \mathrm{~N}$ values in atmospheric nitrate along transport pathways. Long-term collocated measurements of $\delta^{15} \mathrm{~N}$ in atmospheric and rainwater nitrate in remote regions as well as laboratory measurements of the isotope effect associated with the uptake of nitrate into rainwater droplet are needed to address this long-standing issue [Freyer, 1991]. This could have important implications for the interpretation of $\delta^{15} \mathrm{~N}$ records of nitrate in remote areas, in the atmosphere as well as in snow pits and ice cores [Yeatman et al., 2001; Hastings et al., 2003, 2004, 2005; Heaton et al., 2004; Baker et al., 2007; Savarino et al., 2007; Morin et al., 2008; Jarvis et al., 2008].

\subsection{Interpretation of $\delta^{\mathbf{1 5}} \mathbf{N}$ Data in Polar Regions}

[45] Atmospheric nitrate in polar regions originates from long-range transport, with possible contributions from stratospheric input [Legrand and Kirchner, 1990; Weller et al., 2002; Savarino et al., 2007; Wolff et al., 2008]. Moreover, the impact of nitrate recycling in the snow, either through the release of nitric acid from the snow by physical processes such as sublimation or desorption, or the local oxidation of $\mathrm{NO}_{x}$ emitted by the snowpack can also contribute to the local nitrate budget [Domine and Thibert, 1996; Wagnon et al., 1999; Honrath et al., 1999; Nakamura et al., 2000; Jones et al., 2000; Davis et al., 2001; Beine et al., 2002; Grannas et al., 2007; Savarino et al., 2007; Morin et al., 2008].

[46] Our data set clearly shows that in polar regions $\delta^{15} \mathrm{~N}$ in atmospheric nitrate is generally much lower than at midlatitudes (see Figure 6). In addition, samples from the Weddell Sea (Southern Atlantic Ocean) exhibit an anticorrelation of $\delta^{15} \mathrm{~N}$ with the degree of interaction of the air mass with snow-covered surfaces in days preceding the sampling (Figure 10). We argue that, under the conditions of our sampling campaigns, snowpack emissions of $\mathrm{NO}_{x}$ from the snowpack are responsible for these observations. First, a direct influence of the stratosphere is ruled out. Moore [1974] reported $\delta^{15} \mathrm{~N}$ values in stratospheric nitrate (collected at an altitude of approximately $25 \mathrm{~km}$ over Australia and Alaska) ranging from 0.8 to 2.8 . The sign of the measured $\delta^{15} \mathrm{~N}$ is consistent with the calculations of Savarino et al. [2007], suggesting that the stratosphere is not likely a source of nitrate with negative $\delta^{15} \mathrm{~N}$ values. Second, it is now well known that the loss of nitrate from the snowpack is associated with a strong isotopic fractionation, leading to 
Table 1. Overview of the $\delta^{15} \mathrm{~N}$ of Sources of $\mathrm{NO}_{x}$ Reported in the Literature or Estimated in This Study ${ }^{\mathrm{a}}$

\begin{tabular}{|c|c|c|}
\hline Sources & $10^{3} \delta^{15} \mathrm{~N}$ & Reference \\
\hline Thermal $\mathrm{NO}_{x}$ & $\begin{array}{l}\text { Anthropogenic } \\
-13 \text { to }-2\end{array}$ & $\begin{array}{l}\text { Heaton [1990], } \\
\text { Snape et al. }\end{array}$ \\
\hline Fuel $\mathrm{NO}_{x}$ & 6 to 13 & $\begin{array}{l}\text { Heaton [1990], } \\
\quad \text { Snape et al. }[2003]\end{array}$ \\
\hline $\begin{array}{l}\text { Lightning } \mathrm{NO}_{x} \\
\text { Fertilized soil } \mathrm{NO}_{x} \\
\text { Soil } \mathrm{NO}_{x} \\
\text { Biomass burning } \mathrm{NO}_{x}\end{array}$ & $\begin{array}{c}\text { Natural } \\
\simeq 0 \\
-50 \text { to }-20 \\
<-20 \\
?\end{array}$ & $\begin{array}{l}\text { Hoering [1957] } \\
\text { Li and Wang [2008] } \\
\text { Freyer }[1991]\end{array}$ \\
\hline & Polar Regions & \\
\hline Stratospheric nitrate & $\begin{array}{c}0 \text { to } 3 \\
>0\end{array}$ & $\begin{array}{l}\text { Moore [1974] } \\
\text { Savarino et al. }[2007]\end{array}$ \\
\hline Snowpack emissions & $<<<0$ & $\begin{array}{l}\text { Blunier et al. }[2005], \\
\quad \text { Savarino et al. }[2007]\end{array}$ \\
\hline
\end{tabular}

${ }^{\text {a }}$ Also given is the $\delta^{15} \mathrm{~N}$ of sources of atmospheric nitrate in polar regions Snowpack emissions lead to extremely low $\delta^{15} \mathrm{~N}$ values because the fractionation constant $(\varepsilon)$ associated with the nitrate loss process in the snow is large and negative ( $\varepsilon \simeq-54 \%$ [ Blunier et al., 2005]).

an increase of $\delta^{15} \mathrm{~N}$ in the nitrate remaining in the snow [Blunier et al., 2005]. As a result of mass conservation, and provided that the loss constitutes a small fraction of the nitrate content of the snow, the reactive nitrogen species emitted from the snow produced by this process must possess a very low $\delta^{15} \mathrm{~N}$ [Blunier et al., 2005; Savarino et al., 2007; Morin et al., 2008]. On the sole basis of $\delta^{15} \mathrm{~N}$ measurements, it is currently not possible to distinguish between physical release and photolysis of nitrate in the snow, as both processes induce $\delta^{15} \mathrm{~N}$ variations in the same direction, and that the specific fractionation constants $(\varepsilon[$ Criss, 1999]) are poorly characterized [Blunier et al., 2005]. Additional evidence from oxygen isotopic ratios would be required to separate out these two processes.

\subsection{Summary of the Discussion on $\delta^{15} \mathrm{~N}$ Data}

[47] Much of the information critically reviewed above against the new field measurements in nonpolar regions is summarized in Table 1, which gives the likely $\delta^{15} \mathrm{~N}$ of some $\mathrm{NO}_{x}$ and atmospheric nitrate sources. At this stage, several values from Table 1 are only an indication of the range or the sign of the specific signature of the source considered. Given that the isotopic fractionation associated with the $\mathrm{NO}_{x}$ to nitrate conversion step is not known, but believed to be of a few per mil only [Freyer, 1991; Freyer et al., 1993] (see section 5.3 for further evidence), we do not distinguish between $\delta^{15} \mathrm{~N}\left(\mathrm{NO}_{x}\right), \delta^{15} \mathrm{~N}\left(\mathrm{NO}_{2}\right)$ and $\delta^{15} \mathrm{~N}\left(\mathrm{NO}_{3}^{-}\right)$. Only results from rainwater nitrate cannot be compared to such data because the fractionation associated with the incorporation of nitrate into rain droplets is potentially larger (up to 10\%o) and not well characterized hitherto [Freyer, 1991; Baker et al., 2007] (see section 4.1.3). As such, our results and analysis suggest that, in remote places, assigning variations of $\delta^{15} \mathrm{~N}\left(\mathrm{NO}_{3}^{-}\right)$to shifts in $\mathrm{NO}_{x}$ sources (which, with the exception of snowpack emissions, seem to all operate in a rather limited range of $\delta^{15} \mathrm{~N}\left(\mathrm{NO}_{x}\right)$ values) and fractionation of ${ }^{15} \mathrm{~N}$ within $\mathrm{NO}_{x}$ [Hastings et al., 2003,
2004; Jarvis et al., 2008] will only lead to a partial explanation of the observations. Exploring and taking into account the effects of transport of reactive nitrogen on $\delta^{15} \mathrm{~N}\left(\mathrm{NO}_{3}^{-}\right)$is likely to improve our understanding the range of variations and the seasonal trends in remote locations.

\section{Interpretation of the Oxygen Isotopic Ratios of Nitrate}

[48] For clarity, we restrain this analysis to the interpretation of $\Delta^{17} \mathrm{O}$ measurements only. The $\delta^{18} \mathrm{O}$ results have been provided for completeness and for comparison with data sets containing $\delta^{18} \mathrm{O}$ only [e.g., Hastings et al., 2003, $2004,2005]$. The key advantage of using $\Delta^{17} \mathrm{O}$ measurements is that mass-dependent fractionation (arising from kinetic or equilibrium isotopic fractionation) has no impact on the isotope anomaly. $\Delta^{17} \mathrm{O}$ is interpreted using massbalance calculations and simply tracking the origin of oxygen atom(s) transferred during chemical reactions [Michalski et al., 2003; Thiemens, 2006]. It must be realized that using the same mass-balance approach for interpreting $\delta^{18} \mathrm{O}$ measurements would lead to inconsistent results (as recently exemplified by Jarvis et al. [2008]), because isotopic fractionation occurring at each step of any chemical mechanism can induce large variations between $\delta^{18} \mathrm{O}$ values of the reactants and the products, making this approach unsuitable for any quantitative assessment.

\subsection{Interpretation Framework for $\Delta^{17} \mathrm{O}$ of Atmospheric Nitrate}

[49] Michalski et al. [2003] reported the first interpretation of the isotope anomaly $\Delta^{17} \mathrm{O}$ of atmospheric nitrate, and suggested that it stems from the isotope anomaly of tropospheric ozone, through oxygen atom transfer reaction within the $\mathrm{NO}_{x}$-ozone photochemical cycle [Leighton, 1961; Crutzen, 1970] and $\mathrm{NO}_{2}$ to nitrate conversion reactions. Since this pioneering work, several studies have used and refined the framework of Michalski et al. [2003] [e.g., Alexander et al., 2004; Michalski et al., 2005; Morin et al., 2007b; 2008; Mccabe et al., 2007; Savarino et al., 2007, 2008; Patris et al., 2007; Kunasek et al., 2008]. We briefly summarize key equations and concepts necessary to understand the way $\Delta^{17} \mathrm{O}$ values are interpreted. Detailed descriptions are given by Morin et al. [2007b] and Savarino et al. [2008].

[50] At photochemical steady state, $\Delta^{17} \mathrm{O}\left(\mathrm{NO}_{2}\right)$ is given by the following formula:

$$
\Delta^{17} \mathrm{O}\left(\mathrm{NO}_{2}\right)=\alpha \times \Delta^{17} \mathrm{O}\left(\mathrm{O}_{3}^{\star}\right)
$$

where $\Delta^{17} \mathrm{O}\left(\mathrm{O}_{3}^{\star}\right)$ represents the isotope anomaly transferred by ozone during its reaction with $\mathrm{NO}$, which is not equal to $\Delta^{17} \mathrm{O}\left(\mathrm{O}_{3}\right)$ because of the combination of the isotopic asymmetry of ozone [Janssen, 2005; Bhattacharya et al., 2008 ] with the mechanism of the $\mathrm{NO}+\mathrm{O}_{3}$ reaction [Savarino et al., 2008]. $\Delta^{17} \mathrm{O}\left(\mathrm{O}_{3}^{\star}\right)$ was recently determined in the laboratory [Savarino et al., 2008] and is specific for the $\mathrm{NO}+\mathrm{O}_{3}$ reaction,

$$
10^{3} \Delta^{17} \mathrm{O}\left(\mathrm{O}_{3}^{\star}\right)=1.18 \times 10^{3} \Delta^{17} \mathrm{O}(\text { bulk ozone })+6.6
$$


Table 2. Theoretical $\Delta^{17} \mathrm{O}\left(\mathrm{NO}_{3}^{-}\right)$Values Induced by Each Nitrate Formation Pathway, as a Function of $\alpha$ and $\Delta^{17} \mathrm{O}\left(\mathrm{O}_{3}^{\star}\right)^{\mathrm{a}}$

\begin{tabular}{lccc}
\hline & & \multicolumn{2}{c}{$10^{3} \Delta^{17} \mathrm{O}$} \\
\cline { 3 - 4 } \multicolumn{1}{c}{ Process } & $\Delta^{17} \mathrm{O}\left(\mathrm{NO}_{3}^{-}\right)$ & $\alpha=0.7$ & $\alpha=0.95$ \\
\hline & Daytime Process & & \\
$\mathrm{OH}+\mathrm{NO}_{2}$ & $2 \alpha / 3 \times \Delta^{17} \mathrm{O}\left(\mathrm{O}_{3}^{\star}\right)$ & $\mathbf{1 7}$ & $(23)$ \\
$\mathrm{BrONO}_{2}$ hydrolysis & $(2 \alpha+1) / 3 \times \Delta^{17} \mathrm{O}\left(\mathrm{O}_{3}^{\star}\right)$ & $\mathbf{2 9}$ & $(35)$ \\
$\mathrm{HNO}_{4}$ hydrolysis & $3 \alpha / 8 \times \Delta^{17} \mathrm{O}\left(\mathrm{O}_{3}^{\star}\right)$ & $\mathbf{9}$ & $(13)$ \\
$\mathrm{HO}_{2}+\mathrm{NO}$ & $\alpha / 3 \times \Delta^{17} \mathrm{O}\left(\mathrm{O}_{3}^{\star}\right)$ & $\mathbf{8}$ & $(11)$ \\
& & & \\
$\mathrm{N}_{2} \mathrm{O}_{5}$ hydrolysis & Nighttime Process & & \\
$\mathrm{NO}_{3}+\mathrm{RH}$ & $(4 \alpha+1) / 6 \times \Delta^{17} \mathrm{O}\left(\mathrm{O}_{3}^{\star}\right)$ & $(23)$ & $\mathbf{2 9}$ \\
\hline
\end{tabular}

${ }^{\mathrm{a}}$ Morin et al. [2007b] and Michalski et al. [2003]. For these calculations, $\Delta \Delta^{17} \mathrm{O}\left(\mathrm{O}_{3}^{\star}\right)=36 \%$. Values taken for $\alpha$ during the day and the night are 0.7 and 0.95 , respectively. Bold values highlight the matching of predominant irradiation conditions suitable for a given reaction (night or day) with the corresponding value of $\alpha$.

The $\alpha$ reflects the proportion of $\mathrm{O}$ atoms originating from ozone (and $\mathrm{BrO}$ ) in $\mathrm{NO}_{2}$ [Michalski et al., 2003; Morin et al., 2007b]. It is given by the following equation:

$$
\alpha=\frac{k_{O_{3}+\mathrm{NO}}\left[\mathrm{O}_{3}\right]+k_{\mathrm{BrO}+\mathrm{NO}}[\mathrm{BrO}]}{k_{O_{3}+\mathrm{NO}}\left[\mathrm{O}_{3}\right]+k_{\mathrm{BrO} O \mathrm{NO}}[\mathrm{BrO}]+k_{\mathrm{RO}}+\mathrm{NO}\left[\mathrm{RO}_{2}\right]} .
$$

It is assumed that $\mathrm{O}_{3}$ reacts with $\mathrm{Br}$ in a way similar to that with NO in terms of $\Delta^{17} \mathrm{O}$ transfer [Morin et al., 2008]. In equation (5), $\mathrm{RO}_{2}$ represents peroxy radicals and $\mathrm{k}$ values are reaction rate constants of the chemical reactions between $\mathrm{NO}$ and its oxidants $\left(\mathrm{O}_{3}, \mathrm{BrO}\right.$ and $\left.\mathrm{RO}_{2}\right)$. During the day, $\alpha$ is smaller than 1 owing to the role of $\mathrm{RO}_{2}$ in the oxidation of NO. At night, the photochemical cycle breaks down completely and equation (3) can be extended using a value of $\alpha$ close to 1 .

[51] The key variables needed to assess the value of $\Delta^{17} \mathrm{O}\left(\mathrm{NO}_{2}\right)$ are $\Delta^{17} \mathrm{O}\left(\mathrm{O}_{3}\right)$ and $\alpha$. All studies dealing with $\Delta{ }^{17} \mathrm{O}$ of nitrate assume a constant $\Delta^{17} \mathrm{O}$ in tropospheric ozone, although both the exact value and its natural variability are unknown to a large extent. This originates from the discrepancy between laboratory experiments suggesting a low natural variability for $\Delta^{17} \mathrm{O}\left(\mathrm{O}_{3}\right)$ [Brenninkmeijer et al., 2003, and references therein] of a few per mil and actual atmospheric measurements displaying an extended range of $\Delta^{17} \mathrm{O}\left(\mathrm{O}_{3}\right)$ [Krankowsky et al., 1995; Johnston and Thiemens, 1997]. We have recently proposed that a reasonable value for $\Delta^{17} \mathrm{O}\left(\mathrm{O}_{3}\right)$ in the troposphere is $25 \%$, taking into the available measurements [Morin et al., 2007b, 2008; Savarino et al., 2008], which must be used together with the $\Delta^{17} \mathrm{O}$ transfer function determined by Savarino et al. [2008] (equation (4)). We note that this yields results very similar $\left(\Delta^{17} \mathrm{O}\left(\mathrm{O}_{3}^{\star}\right)=36 \%\right.$ o $)$ to what is obtained using a value of $35 \%$ for $\Delta^{17} \mathrm{O}\left(\mathrm{O}_{3}\right)$ and using the crude assumption that all oxygen atoms of ozone are isotopically equivalent. This approach was used by Michalski et al. [2003] and many subsequent studies [Alexander et al., 2004; Michalski et al., 2005; Morin et al., 2007b; Patris et al., 2007; Kunasek et al., 2008]. Using any of these two approaches thus yields the same results in terms of predicting the value of $\Delta^{17} \mathrm{O}\left(\mathrm{NO}_{3}^{-}\right)$, although our formalism is consistent with experimental evidence on the transfer of $\Delta^{17} \mathrm{O}$ during the $\mathrm{NO}+\mathrm{O}_{3}$ reaction and on the measured value of atmospheric $\Delta \Delta^{17} \mathrm{O}\left(\mathrm{O}_{3}\right)$ [Savarino et al., 2008]. The $\alpha$ is a purely photochemical variable and can be determined using atmospheric models [Michalski et al., 2003; Morin et al., 2008; Kunasek et al., 2008].

[52] Several formation pathways operate to convert $\mathrm{NO}_{2}$ to atmospheric nitrate. Michalski et al. [2003] realized that each one of them yields the incorporation of an additional $\mathrm{O}$ atom originating from various species (e.g., $\mathrm{O}_{3}, \mathrm{OH}$ ). Identifying the chemical origin of this additional $\mathrm{O}$ atom, and knowing the isotopic anomaly it carries, allows to predict the isotope anomaly of nitrate formed through each formation pathway. This has been explored in greater details by Michalski et al. [2003] and Morin et al. [2007b]. In this study, we add the signature of two additional potentially significant nitrate formation pathways, namely the hydrolysis of $\mathrm{HNO}_{4}$ [Dentener et al., 2002] and the $\mathrm{HO}_{2}+\mathrm{NO}$ reaction [Cariolle et al., 2008]. $\mathrm{HNO}_{4}$ originates from the reaction of $\mathrm{HO}_{2}$ with $\mathrm{NO}_{2}$. With the simplifying assumption that $\Delta^{17} \mathrm{O}\left(\mathrm{HO}_{2}\right)=0 \%$, the $\Delta^{17} \mathrm{O}$ of nitrate produced through these two channels can be calculated. Indeed, the isotope anomaly of $\mathrm{HO}_{2}$ is expected to be on the order of 1-2\%o [Savarino and Thiemens, 1999a, 1999b], which is negligible in the frame of this study. Table 2 summarizes the predicted $\Delta^{17} \mathrm{O}$ in nitrate produced upon the different reaction pathways, as a function of the $\alpha$ value (full details are given elsewhere [Michalski et al., 2003; Morin et al., 2007b, 2008]).

[53] We believe that much of the variance in $\Delta^{17} \mathrm{O}\left(\mathrm{NO}_{3}^{-}\right)$ originates from changes in the proportions between nitrate formation pathways. The real impact of the variability of $\Delta{ }^{17} \mathrm{O}\left(\mathrm{O}_{3}\right)$ cannot be assessed at present owing to the paucity of tropospheric ozone $\Delta^{17} \mathrm{O}$ measurements. In this study, we use a value of $\Delta^{17} \mathrm{O}=25 \%$ [Savarino et al., 2008; Morin et al., 2008] and neglect any cause of natural variability for this variable consistent with all studies carried out hitherto. The impact of changes in $\alpha$ values are also difficult to assess without conducting a thorough modeling evaluation of the temporal and geographical variations of this variable [Kunasek et al., 2008]. In this study, we use $\alpha$ values obtained from the results of a box model, representing the midlatitude MBL at day (0.7) and night (0.95) [Morin et al., 2008; N. Yan and S. Bekki, personal communication, 2008]. Further sensitivity tests performed using the same box model show that $\alpha$ only weakly depends on the mixing ratio of ozone. It does not significantly change when ozone levels double from about 20 to $40 \mathrm{nmol} \mathrm{mol}^{-1}$ similar to what was observed at the ITCZ boundary. This is consistent with the results of Kunasek et al. [2008] showing an effect lower than $1 \%$ in terms of $\Delta^{17} \mathrm{O}\left(\mathrm{NO}_{3}^{-}\right)$for a doubling of the role taken by ozone in $\mathrm{NO}$ oxidation. Typical values expected for $\Delta^{17} \mathrm{O}\left(\mathrm{NO}_{3}^{-}\right)$produced by the different $\mathrm{NO}_{x}$ conversion pathways are given in Table 2 . The values in Table 2 should be viewed as indicative of the signatures of the mechanisms involved in a broad sense. Only a model incorporating diurnal variations of the key atmospheric variables governing nitrate formation pathway will yield values really comparable with the measured data [e.g., Morin et al., 2008; Kunasek et al., 2008]. Nevertheless, despite some overlap in the signature of the different nitrate production pathways, temporal and/or geographical 
variations of $\Delta^{17} \mathrm{O}$ have to be traced back to changes in the proportions of $\mathrm{NO}_{x}$ oxidation pathways, despite significant uncertainties pertaining to some aspects of this young research field [Morin et al., 2008; Kunasek et al., 2008].

\subsection{Oxygen Isotopic Ratios in Low-Latitude Regions}

[54] In nonpolar regions $\Delta^{17} \mathrm{O}$ is relatively constant. In the Southern Hemisphere it is on the order of $(26 \pm 2) \%$. In the Northern Hemisphere values are somewhat higher on the order of $(29 \pm 2) \%$. The ITCZ is associated with a steep increase $\left(3 \%\right.$ ) in $\Delta^{17} \mathrm{O}$ as a function of latitude (see Figure 7).

[55] These observations can be interpreted in terms of $\mathrm{NO}_{x}$ removal reaction pathways, although a precise apportionment is impeded by overlapping $\Delta^{17} \mathrm{O}$ signatures of the pathways contributing to nitrate formation. The major $\mathrm{NO}_{x}$ loss processes suspected to operate significantly in the MBL are the $\mathrm{OH}+\mathrm{NO}_{2}$ reaction and the hydrolysis of $\mathrm{N}_{2} \mathrm{O}_{5}$, with a potential contribution of the reaction of $\mathrm{NO}_{3}$ with hydrocarbons or reduced sulfur compounds and the halogen nitrate hydrolysis (such as $\mathrm{BrONO}_{2}$ ) [Dentener and Crutzen, 1993; Sander et al., 1999; Michalski et al., 2003; Evans and Jacob, 2005; Penkett et al., 2007; Patris et al., 2007; Read et al., 2008]. Our data show that nitrate production does not seem to occur in major proportions through the reaction of $\mathrm{OH}$ with $\mathrm{NO}_{2}$, because this channels leads to $\Delta^{17} \mathrm{O}$ values much lower than observed. Although their contribution cannot be ruled out on the basis of $\Delta^{17} \mathrm{O}$ only, it appears that the $\mathrm{HNO}_{4}$ hydrolysis pathway [Dentener et al., 2002] and the $\mathrm{HO}_{2}+\mathrm{NO}$ pathway [Cariolle et al., 2008] do not play a major role in nitrate formation in the MBL. As described above and in Table 2, production channels involving heterogeneous reactions such as the hydrolysis of $\mathrm{BrONO}_{2}$ or $\mathrm{N}_{2} \mathrm{O}_{5}$ lead to higher $\Delta^{17} \mathrm{O}$ values, because of a higher involvement of ozone in these $\mathrm{NO}_{2}$ oxidation pathways [Morin et al., 2007b]. High $\Delta^{17} \mathrm{O}$ values are also expected from the $\mathrm{H}$ abstraction from a volatile organic compound (including DMS) by the nitrate radical $\left(\mathrm{NO}_{3}\right)$. Recent investigations suggest this pathway to be a significant source of nitrate in the MBL [Vrekoussis et al., 2006; Stark et al., 2007; Penkett et al., 2007]. Higher than anticipated $\mathrm{BrO}$ levels have recently been reported for the Atlantic MBL [Read et al., 2008]. Its impact in terms of $\mathrm{BrONO}_{2}$ formation, hence nitrate production through its hydrolysis [Sander et al., 1999], is not assessed at the moment.

[56] The main implication of these observations is that heterogeneous/nighttime reactions (i.e., involving $\mathrm{O}_{3}$ as the main $\mathrm{NO}_{2}$ oxidant) are playing a major role in terms of nitrate sources, so that the $\mathrm{OH}+\mathrm{NO}_{2}$ reaction cannot be viewed as the only transformation pathway of $\mathrm{NO}_{x}$ to nitrate. This is consistent with recent reports claiming that nocturnal $\mathrm{NO}_{x}$ processing plays a key role for the budget of reactive nitrogen [Brown et al., 2004, 2006] and the oxidative capacity of the atmosphere [Penkett et al., 2007] and that reactions involving $\mathrm{N}_{2} \mathrm{O}_{5}$ are particularly important [Dentener and Crutzen, 1993; Evans and Jacob, 2005; Osthoff et al., 2006, 2008]. The increase seen at the ITCZ boundary suggests an even larger role for these processes in the Northern Hemisphere, possibly due to larger aerosol surface area in the case of the heterogeneous reactions such as $\mathrm{N}_{2} \mathrm{O}_{5}$ hydrolysis. Only a thorough comparison of our data with the output of large-scale modeling studies [e.g., Hastings and Alexander, 2006] will lead to a more quantitative assessment of the increment of knowledge permitted by $\Delta^{17} \mathrm{O}$ measurements in nitrate.

\subsection{Discussion of the Size-Segregated Measurements}

[57] The observations that $\Delta^{17} \mathrm{O}$ in the supermicron mode was substantially higher than in the submicron mode unexpectedly points toward different atmospheric nitrate formation mechanisms as a function of the size of the particles. Patris et al. [2007] observed the same behavior. They concluded qualitatively that the $\mathrm{OH}+\mathrm{NO}_{2}$ pathway had a larger influence on nitrate in the submicron mode, although it plays only a minor role for nitrate collected in the coarse aerosol fraction. This is supported by the case study of the pollution plume sampled south of the Canary Islands. Elevated $\delta^{15} \mathrm{~N}$ in atmospheric nitrate attributed to anthropogenic $\mathrm{NO}_{x}$ was only observed in submicron particles, in conjunction with lower $\Delta^{17} \mathrm{O}$ than over the open ocean (see Figure 7). This suggests that the oxidation of $\mathrm{NO}_{x}$ in a pollution plume operates to a large extent through the formation of gas-phase $\mathrm{HNO}_{3}$, which is more incorporated in smaller particles than in coarse particles. However, the results may also be the consequence of direct uptake of $\mathrm{HNO}_{3}$ on the plain filter used to collect submicron particles (see section 2.1).

[58] In the case of uptake of nitrate to the surface of aerosols, the size of the particles itself is not expected to have a strong influence. In contrast, the chemical composition of the particles differs markedly [e.g., Virkkula et al., 2006a], with submicron particles consisting mostly of sulfate in the form of either acidic sulfuric particles or as neutralized ammonium sulfate. Supermicron particles are mostly consisting of sea salt and dust (especially on the western coast of Africa) [Virkkula et al., 2006a]. Its is known that heterogeneous reactions proceed at different rates on chemically different surfaces [Evans and Jacob, 2005; Brown et al., 2006]. Size-segregated $\Delta^{17} \mathrm{O}$ measurements, combined with measurements of the chemical composition of the particles in the size fractions, offer an opportunity to investigate this directly in the field.

[59] We tentatively suggest from our analysis that the difference of $\Delta^{17} \mathrm{O}$ in different size fractions is due to the fact that mostly nighttime, heterogeneous reactions at the surface of dust or sea salt particles lead to the formation of nitrate on coarse mode particles. Submicron particles (possibly including the direct contribution of gas-phase $\mathrm{HNO}_{3}$ ) are more influenced by homogeneous, daytime $\mathrm{HNO}_{3}$ formation reactions. Our conclusions would have large implications for the understanding of the interactions between reactive nitrogen and aerosols [Brown et al., 2006]. So far it has been assumed that nitric acid uptake on coarse particles would be the main cause for its presence in the supermicron mode [Bauer et al., 2007]. Although nitric acid uptake (e.g., in the form of ammonium nitrate) seems to contribute significantly to the budget of submicron atmospheric nitrate, our observations on supermicron aerosol nitrate suggest that nitrate is rather formed heterogeneously on these particles. Simultaneous measurements of reactive nitrogen (including the $\mathrm{NO}_{3}$ radical and $\mathrm{N}_{2} \mathrm{O}_{5}$ ), halogen oxides, DMS and $\Delta^{17} \mathrm{O}$ of size-segregated nitrate aerosol (possibly including specific sampling of gas-phase $\mathrm{HNO}_{3}$ 
by means of wet-chemistry methods, such as denuders or mist chambers) at a given marine site can help to resolve this issue regarding reactive nitrogen transformation and atmospheric nitrate formation.

[60] The observation that chemical mechanisms for the $\mathrm{NO}_{x}$ to nitrate conversion operate in different proportions as a function of the particle size (revealed by $\Delta^{17} \mathrm{O}$ measurements) has to be confronted to the size-segregated $\delta^{15} \mathrm{~N}$ data, which show no such systematic difference. Whether $\mathrm{NO}_{x}$ to nitrate conversion pathways induce different isotopic fractionation has been discussed by Freyer [1991], who considered the effect to be small, within a few per mil (see above). Our data suggest that this effect could be even smaller, because we do not see any evidence for a different $\delta^{15} \mathrm{~N}$ value in nitrate produced by different formation pathways under similar atmospheric conditions.

\subsection{Interpretation of $\Delta^{17} \mathrm{O}$ Data in Polar Regions}

[61] In polar regions, $\Delta^{17} \mathrm{O}$ exhibits larger variability with values generally higher than at midlatitudes (Figure 6). For example, the average value at $\mathrm{Ny}$-Ålesund in spring 2006 was $(35 \pm 2) \%$. We have previously shown that this observed peculiarity of $\Delta^{17} \mathrm{O}$ of atmospheric nitrate in polar regions during the springtime, which is the case for most samples presented here, was most likely due the involvement of the $\mathrm{BrONO}_{2}$ hydrolysis in terms of the nitrate formation pathway in the polar springtime [Morin et al., 2007a, 2007b, 2008]. Indeed in the polar atmosphere during springtime the value of $\alpha$ is of the order of 0.9 even under permanent daytime conditions, so that the hydrolysis of $\mathrm{BrONO}_{2}$ is a channel leading to elevated isotope anomalies in atmospheric nitrate, on the order of 35\% [Morin et al., 2007b, 2008].

[62] The interaction of reactive halogens (most notably BrO) with $\mathrm{NO}_{x}$, and the subsequent incorporation of an elevated isotope anomaly in atmospheric nitrate through the hydrolysis of $\mathrm{BrONO}_{2}$ can only occur if significant levels of $\mathrm{BrO}$ and $\mathrm{NO}_{x}$ are present in the polar atmosphere. We recall that the $\Delta^{17} \mathrm{O}\left(\mathrm{NO}_{3}^{-}\right)$measurements were carried out during spring, when ozone depletion events usually occur in polar coastal regions [Simpson et al., 2007; Saiz-Lopez et al., 2007]. In both cases (Weddell Sea and Ny-Ålesund), several moderate ozone depletion events were observed. Satellite observations of tropospheric BrO [Wagner et al., 2001; Richter et al., 2002] reveal that $\mathrm{BrO}$ is ubiquitous in polar regions in springtime, even if ozone depletion events are only sporadically observed at coastal sites [Tarasick and Bottenheim, 2002; Simpson et al., 2007]. This strongly suggests that, even without continuous depletion of ozone, $\mathrm{BrO}$ plays an active role in the chemical budget of $\mathrm{NO}_{x}$ in the polar spring, that is imprinted in the $\Delta^{17} \mathrm{O}$ signature of atmospheric nitrate (see Table 2). The analysis of the time series of $\Delta^{17} \mathrm{O}$ and $\delta^{15} \mathrm{~N}$ at $\mathrm{Ny}$-Alesund shows evidence of the coupling between snowpack $\mathrm{NO}_{x}$ emissions and reactive halogen chemistry. In this record (Figure 9), it was observed that episodes of extremely low $\delta^{15} \mathrm{~N}$ concur with the highest $\Delta^{17} \mathrm{O}$ values, strongly suggesting that gaining a local isotopic signature in terms of $\Delta^{17} \mathrm{O}$ (i.e., halogen/ $\mathrm{NO}_{x}$ interactions) is only made possible by local injection of $\mathrm{NO}_{x}$ to the atmosphere through snowpack emissions [Savarino et al., 2007; Morin et al., 2008]. This supports our hypothesis that nitrate recycling in the snow leads to
$\mathrm{NO}_{x}$ emissions in amounts sufficient to impact the atmospheric processing of $\mathrm{NO}_{x}$ and nitrate in the overlying boundary layer (in addition to possible $\mathrm{HNO}_{3}$ evaporation) [Morin et al., 2008].

\section{Summary}

[63] This study represents the largest geographically resolved record of the comprehensive isotopic composition of atmospheric nitrate $\left(\mathrm{HNO}_{3}+\mathrm{p}-\mathrm{NO}_{3}^{-}\right)$. It covers an extended latitudinal range from $65^{\circ} \mathrm{S}$ to $79^{\circ} \mathrm{N}$ over the Atlantic Ocean, and most areas have been sampled during the hemispheric spring.

[64] In low-latitude regions over the Atlantic Ocean, the $\delta^{15} \mathrm{~N}$ measurements suggest a quite uniform distribution of the sources of $\mathrm{NO}_{x}$, from which atmospheric nitrate forms. In contrast, $\Delta^{17} \mathrm{O}$ reveals strong latitudinal variations in the chemical processing of $\mathrm{NO}_{x}$, in particular at the ITCZ boundary. Our results are consistent with a major contribution of heterogeneous processes such as $\mathrm{N}_{2} \mathrm{O}_{5}$ hydrolysis [Dentener and Crutzen, 1993], that is higher in the Northern Hemisphere than in the Southern Hemisphere. In addition, our data shows a significant difference in $\Delta^{17} \mathrm{O}$ across size fractions of samples collected at the same location, in agreement with the recent study of Patris et al. [2007]. This seems to indicate that the proportion between nitrate formation pathways depends on the size (thus the chemical composition) of the particles on which nitrate ends up. This observation is consistent with the fact that $\mathrm{N}_{2} \mathrm{O}_{5}$ hydrolysis efficiency depend upon the chemical composition of the particles [Evans and Jacob, 2005; Brown et al., 2006].

[65] In polar regions, the data collected in the High Arctic at Ny-Ålesund, Svalbard and in the Weddell Sea show a distinct $\delta^{15} \mathrm{~N}$ signature, most likely due to emissions of $\mathrm{NO}_{x}$ from the snowpack. The observation that the $\delta^{15} \mathrm{~N}$ signature originating from this source correlates with the time of travel of air masses over sea ice covered areas seems to indicate that such emissions are not restricted to continental snow, but also snow covering sea ice, which has implications in terms of the regional (or even global) impact of this $\mathrm{NO}_{x}$ source to the atmosphere [Carver et al., 2004]. Our data are in agreement with recent results inferred from the isotopic composition of nitrate in the Arctic atmosphere [Morin et al., 2008], that $\mathrm{NO}_{x}$ emitted from the snowpack strongly interact with halogen oxides such as $\mathrm{BrO}$ to form nitrate through the hydrolysis of $\mathrm{BrONO}_{2}$.

\section{Implications}

[66] This study clearly demonstrates that nitrogen and oxygen stable isotopic ratios in atmospheric nitrate are governed by a combination of atmospheric processes. Moreover, the coupled interpretation of the $\delta^{15} \mathrm{~N}$ and $\Delta^{17} \mathrm{O}$ in atmospheric nitrate holds great potential for deciphering atmospheric phenomena that cannot be separated by concentration measurements alone. $\Delta^{17} \mathrm{O}$ values can easily be derived from chemical budgets determined during the model runs, thereby providing a new way to control the ability of the model to represent atmospheric processes [e.g., Michalski et al., 2003; Kunasek et al., 2008]. In this regard, we expect that the increase in the global coverage of $\Delta^{17} \mathrm{O}$ of atmospheric nitrate will bring 
new constraints for modeling work carried out at the regional to global scale [Hastings and Alexander, 2006]. Atmospheric modeling of reactive nitrogen should integrate our observation that nitrate formation pathways proceed in different proportions as a function of the particle sizes (thus, chemical composition). More size-segregated isotopic measurements are required to base this suggestion on stronger evidence [Patris et al., 2007].

[67] In polar areas, this study reinforces the conclusions of recent studies demonstrating that loss of nitrate from the snow leads to significant reemissions of reactive nitrogen into the overlying atmosphere [Savarino et al., 2007; Morin et al., 2008], confirming by independent means the chemical observations carried out in or above polar snowpacks [Honrath et al., 1999; Jones et al., 2000; Ridley et al., 2000; Beine et al., 2002; Grannas et al., 2007; Davis et al., 2008]. From a stable isotope perspective, coupled studies of nitrogen and oxygen stable isotopic ratios in the snowpack holds promises as to whether photolysis and release by physical processes of nitrate can be independently quantified, a topic currently under investigation in our laboratory.

[68] The last implication of this work pertains to the use of $\delta^{15} \mathrm{~N}$ of ice-core nitrate to infer atmospheric information. For instance, Hastings et al. [2005] showed that $\delta^{15} \mathrm{~N}$ of nitrate recovered from the GISP ice core (Summit, Greenland) has a mean value of $9.7 \%$ during the Holocene period and $28.4 \%$ during the Last Glacial Maximum (LGM). Present-day $\delta^{15} \mathrm{~N}$ in nitrate from the Greenland snowpack exhibits seasonal variations between -10 and 10\%o [Hastings et al., 2004], which are consistent with the seasonal cycle derived from a coastal Arctic station [Morin et al., 2008]. In their ice-core study, Hastings et al. [2005] dismissed stronger postdepositional loss of nitrate as a valid candidate to explain the higher $\delta^{15} \mathrm{~N}$ measured during the LGM, and argued that changes in the sources of nitrate (or in the atmospheric cycle of reactive nitrogen) across climatic cycles was responsible for this observations. In particular, they proposed that biomass burning or soil $\mathrm{NO}_{x}$ should carry extremely high $\delta^{15} \mathrm{~N}$ signature, on the order of $+30 \%$ to account for their observations. Our observations in regions where biomass burning and soil emissions are active sources of $\mathrm{NO}_{x}$ do not support this hypothesis. In addition, our analysis does not suggest that any significant source of $\mathrm{NO}_{x}$ carries a strongly positive $\delta^{15} \mathrm{~N}$ signature able to match the measurements carried out in ice cores. Postdepositional loss of nitrate from the snow, enhanced at times where accumulation was lower [Freyer et al., 1996; Blunier et al., 2005; Savarino et al., 2007; Wolff et al., 2008], is the most likely candidate to account for the observations of Hastings et al. [2005]. In summary, caution is warranted in relating $\delta^{15} \mathrm{~N}\left(\mathrm{NO}_{3}^{-}\right)$in firn and ice cores to past atmospheric conditions before the site-specific isotopic atmosphere-to-snow transfer is reasonably understood. Moreover, the large difference between $\delta^{15} \mathrm{~N}$ values measured in polar regions and at midlatitudes (see, e.g., Figure 6) strongly suggest that processes such as postdepositional loss of nitrate from the snow and fractionation occurring during the transport of air masses to polar regions are the main drivers of changes of $\delta^{15} \mathrm{~N}$ of nitrate in the polar atmosphere [Morin et al., 2008] and in the nitrate recovered from shallow snowpits [Heaton et al., 2004; Hastings et al., 2004]. These results cast serious doubts on any interpretation solely based on sea- sonal source changes to interpret seasonal variations of $\delta^{15} \mathrm{~N}$ at remote sites [Hastings et al., 2003, 2004; Jarvis et al., 2008]. More multiisotope work is required to put further constrains on such processes. We also suggest long-term investigations of the seasonal cycle of $\delta^{15} \mathrm{~N}$ and in $\Delta^{17} \mathrm{O}$ in atmospheric and precipitation nitrate at sites exposed to various environmental conditions.

[69] Acknowledgments. Many institutions and individuals have helped making this work possible. For support of field measurements we acknowledge IPEV (projects IOANA 2006 and ANTARFROST 2006), AWI (cruises ANT XXIII/4 and ANT XXIII/10) and LGGE. Thanks are owed to the AWIPEV personnel for logistical support at Ny-Alesund, and in particular A. Hormes for keeping our instrument running in March 2006. We thank S. Solberg of NILU for providing ozone measurements at NyAlesund. Thanks are expressed to the crew of the R/V Polarstern and to A. Macke and his team for support onboard. J. Kaiser and D. Sigman are acknowledged for sharing their analytical technique. We thank Envirhonalp for its support through the plateau MOME, Erwann Vince for bacterial cultures at LTHE, and J.-P. Balestrieri, A. Manouvrier, and P. Possenti for technical support at LGGE. Analytical help from A. Grudzieu, J. Erbland, S. Preunkert, and M. De Angelis is gratefully acknowledged. We thank $X$. Tian-Kunze for performing the calculations of contact times of air parcels with snow covered surfaces, and N. Yan and S. Bekki for the chemical box-model calculations. This work was partially funded through the INSU/LEFE-CHAT program and the European Science Foundation (ESF) under the EUROCORES Programme EuroCLIMATE, through contract ERAS-CT-2003-980409 of the European Commission, DG Research, FP6. S.M. acknowledges ENPC for financial support. The Weddell Sea field experiment was coordinated within the IGBP IGAC/SOLAS AICIIPY project. Polar aspects of this work contribute to the OASIS-IPY project. We thank three anonymous reviewers for useful comments.

\section{References}

Alexander, B., J. Savarino, K. J. Kreutz, and M. H. Thiemens (2004), Impact of preindustrial biomass-burning emissions on the oxidation pathways of tropospheric sulfur and nitrogen, J. Geophys. Res., 109, D08303, doi:10.1029/2003JD004218.

Ammann, M., R. Siegwolf, F. Pichlmayer, M. Suter, M. Saurer, and C. Brunold (1999), Estimating the uptake of traffic-derived $\mathrm{NO}_{2}$ from ${ }^{15} \mathrm{~N}$ abundance in Norway spruce needles, Oecologia, 118, 124-131.

Bai, H., C. Lu, and Y. M. Ling (1995), A theoretical study on the evaporation of dry ammonium chloride and ammonium nitrate aerosols, Atmos. Environ., 29, 313-321.

Baker, A. R., K. Westin, S. D. Kelly, M. Voss, P. Streu, and J. N. Cape (2007), Dry and wet deposition of nutrients from the tropical Atlantic atmosphere: Links to primary productivity and nitrogen fixation, Deep Sea Res., Part I, 54, 1704-1720, doi:10.1016/j.dsr.2007.07.001.

Bauer, S. E., D. Koch, N. Unger, S. M. Metzger, D. T. Shindell, and D. G. Streets (2007), Nitrate aerosols today and in 2030: A global simulation including aerosols and tropospheric ozone, Atmos. Chem. Phys., 7 , 5043-5059

Beine, H. J., R. E. Honrath, F. Dominé, W. R. Simpson, and J. D. Fuentes (2002), $\mathrm{NO}_{x}$ during background and ozone depletion periods at Alert: Fluxes above the snow surface, J. Geophys. Res., 107(D21), 4584, doi:10.1029/2002JD002082.

Bhattacharya, S. K., A. Pandey, and J. Savarino (2008), Determination of intramolecular isotope distribution of ozone by oxidation reaction with silver metal, J. Geophys. Res., 113, D03303, doi:10.1029/2006JD008309.

Bigeleisen, J. (1952), The effects of isotopic substitutions on the rates of chemical reactions, J. Phys. Chem., 56, 823-828, doi:10.1021/ j150499a002.

Blunier, T., G. L. Floch, H.-W. Jacobi, and E. Quansah (2005), Isotopic view on nitrate loss in Antarctic surface snow, Geophys. Res. Lett., 32, L13501, doi:10.1029/2005GL023011.

Böhlke, J. K., S. J. Mroczkowski, and T. B. Coplen (2003), Oxygen isotopes in nitrate: New reference materials for ${ }^{18} \mathrm{O}:{ }^{17} \mathrm{O}:{ }^{16} \mathrm{O}$ measurements and observations on nitrate-water equilibration, Rapid Commun. Mass Spectrom., 17, 1835-1846.

Brenninkmeijer, C. A. M., C. Janssen, J. Kaiser, T. Röckmann, T. S. Rhee, and S. S. Assonov (2003), Isotope effects in the chemistry of atmospheric trace compounds, Chem. Rev., 103(12), 5125-5162, doi:10.1021/ cr020644k.

Brown, S. S., et al. (2004), Nighttime removal of $\mathrm{NO}_{x}$ in the summer marine boundary layer, Geophys. Res. Lett., 31, L07108, doi:10.1029/ 2004GL019412. 
Brown, S. S., et al. (2006), Variability in nocturnal nitrogen oxide processing and its role in regional air quality, Science, 311, 67-70, doi:10.1126/ science. 1120120 .

Cariolle, D., M. J. Evans, M. P. Chipperfield, N. Butkovskaya, A. Kukui, and G. Le Bras (2008), Impact of the new $\mathrm{HNO}_{3}$-forming channel of the $\mathrm{HO}_{2}+\mathrm{NO}$ reaction on tropospheric $\mathrm{HNO} 3, \mathrm{NO}_{x}, \mathrm{HO}_{x}$ and ozone, Atmos. Chem. Phys., 8, 4061-4068.

Carver, G., A. E. Jones, and E. W. Wolff (2004), Global modelling of $\mathrm{NO}_{x}$ emissions from snow, Eos Trans. $A G U$, 88(47), Fall Meet. Suppl., Abstract A11B-0048.

Casciotti, K. L., D. M. Sigman, M. G. Hastings, J. K. Böhlke, and A. Hilkert (2002), Measurement of the oxygen isotopic composition of nitrate in seawater and freshwater using the denitrifier method, Anal. Chem., 74, 4905-4912, doi:10.1021/ac020113w.

Criss, R. E. (1999), Principles of Stable Isotope Distribution, Oxford Univ. Press, New York.

Crutzen, P. J. (1970), The influence of nitrogen oxides on the atmospheric ozone content, O. J. R. Meteorol. Soc., 96, 320-325.

Davidson, E. A., and W. Kingerlee (1997), A global inventory of nitric oxide emissions from soils, Nutr. Cycl. Agroecosyst., 48, 37-50.

Davis, D., et al. (2001), Unexpected high levels of NO observed at South Pole, Geophys. Res. Lett., 28(19), 3625-3628.

Davis, D. D., et al. (2008), A reassessment of Antarctic plateau reactive nitrogen based on ANTCI 2003 airborne and ground based measurements, Atmos. Environ., 42, $2831-2848$, doi:10.1016/j.atmosenv. 2007.07.039.

Dentener, F. J., and P. J. Crutzen (1993), Reaction of $\mathrm{N}_{2} \mathrm{O}_{5}$ on tropospheric aerosols: Impact on the global distribution of $\mathrm{NO}_{x}, \mathrm{O}_{3}$ and $\mathrm{OH}$, J. Geophys. Res., 98(D4), 7149-7163.

Dentener, F., J. Williams, and S. Metzger (2002), Aqueous phase reaction of $\mathrm{HNO}_{4}$ : The impact on tropospheric chemistry, J. Atmos. Chem., 41, $109-134$.

Dominé, F., and P. B. Shepson (2002), Air-snow interactions and atmospheric chemistry, Science, 297, 1506-1510.

Dominé, F., and E. Thibert (1996), Mechanism of incorporation of trace gases in ice grown from the gas phase, Geophys. Res. Lett., 23(24), $3627-3630$.

Duce, R. A., et al. (2008), Impacts of atmospheric anthropogenic nitrogen on the open ocean, Science, 320, 893-897, doi:10.1126/science. 1150369.

Elliott, E. M., C. Kendall, S. D. Wankel, D. A. Burns, E. W. Boyer, K. Harlin, D. J. Bain, and T. J. Butler (2007), Nitrogen isotopes as indicators of $\mathrm{NO}_{x}$ source contributions to atmospheric nitrate deposition across the midwestern and northeastern United States, Environ. Sci. Technol., 41(22), 7661-7667, doi:10.1021/es070898t.

Evans, M. J., and D. J. Jacob (2005), Impact of new laboratory studies of $\mathrm{N}_{2} \mathrm{O}_{5}$ hydrolysis on global model budgets of tropospheric nitrogen oxides, ozone, and OH, Geophys. Res. Lett., 32, L09813, doi:10.1029/ 2005 GL022469.

Evans, M. J., et al. (2003), Coupled evolution of $\mathrm{BrO}_{x}-\mathrm{ClO}_{x}-\mathrm{HO}_{x}-\mathrm{NO}_{x}$ chemistry during bromine-catalyzed ozone depletion events in the arctic boundary layer, J. Geophys. Res., 108(D4), 8368, doi:10.1029/ 2002JD002732.

Finlayson-Pitts, B. J., and J. N. Pitts (2000), Chemistry of the Upper and Lower Atmosphere: Theory, Experiments and Applications, Academic Press, San Diego, Calif.

Freyer, H. D. (1991), Seasonal variation of ${ }^{15} \mathrm{~N} /{ }^{14} \mathrm{~N}$ ratios in atmospheric nitrate species, Tellus, Ser. B, 43, 30-44.

Freyer, H. D., D. Kley, A. Volz-Thomas, and K. Kobel (1993), On the interaction of isotopic exchange processes with photochemical reactions in atmospheric oxides of nitrogen, J. Geophys. Res., 98(D8), 14,791$14,796$.

Freyer, H. D., K. Kobel, R. J. Delmas, D. Kley, and M. R. Legrand (1996), First results of ${ }^{15} \mathrm{~N} /{ }^{14} \mathrm{~N}$ ratios in nitrate from alpine and polar ice cores, Tellus, Ser. B, 48, 93-105.

Frieß, U., J. Hollwedel, G. König-Langlo, and T. Wagner (2004), Dynamics and chemistry of tropospheric bromine explosion events in the Antarctic coastal region, J. Geophys. Res., 109, D06305, doi:10.1029/ 2003JD004133.

Galloway, J. N., A. R. Townsend, J. W. Erisman, M. Bekunda, Z. Cai, J. R. Freney, L. A. Martinelli, S. P. Seitzinger, and M. A. Sutton (2008), Transformations of the nitrogen cycle: Recent trends, questions, and potential solutions, Science, 320, 889-892, doi:10.1126/science. 1136674.

Grannas, A. M., et al. (2007), An overview of snow photochemistry: Evidence, mechanisms and impacts, Atmos. Chem. Phys., 7, 4329-4373.

Hara, K., K. Osada, M. Hayashi, K. Matsunaga, T. Shibata, Y. Iwasaka, and K. Furuya (1999), Fractionation of inorganic nitrates in winter arctic troposphere: Coarse aerosol particles containing inorganic nitrates, J. Geophys. Res., 104(D19), 23,671-23,679.
Hastings, M. G., and B. Alexander (2006), First global modeling of the oxygen isotopic composition of atmospheric nitrate, , Eos Trans. AGU, 87(52), Fall Meet. Suppl., Abstract B12A-01.

Hastings, M. G., D. M. Sigman, and F. Lipschultz (2003), Isotopic evidence for source changes of nitrate in rain at Bermuda, J. Geophys. Res. 108(D24), 4790, doi:10.1029/2003JD003789.

Hastings, M. G., E. J. Steig, and D. M. Sigman (2004), Seasonal variations in $\mathrm{N}$ and $\mathrm{O}$ isotopes of nitrate in snow at Summit, Greenland: Implications for the study of nitrate in snow and ice cores, J. Geophys. Res., 109, D20306, doi:10.1029/2004JD004991.

Hastings, M. G., E. J. Steig, and D. M. Sigman (2005), Glacial/interglacial changes in the isotopes of nitrate from the Greenland Ice Sheet Project 2 (GISP2) ice core, Global Biogeochem. Cycles, 19, GB4024, doi:10.1029/ 2005 GB002502.

Heaton, T. H. E. (1990), ${ }^{15} \mathrm{~N} /{ }^{14} \mathrm{~N}$ ratios of $\mathrm{NO}_{x}$ from vehicles engines and coal-fired power stations, Tellus, Ser. B, 42, 304-307.

Heaton, T. H. E., P. Wynn, and A. Tye $(2004)$, Low ${ }^{15} \mathrm{~N} /{ }^{14} \mathrm{~N}$ ratios for nitrate in snow in the High Arctic $\left(79^{\circ} \mathrm{N}\right)$, Atmos. Environ., 38, 56115621, doi:10.1016/j.atmosenv.2004.06.028.

Hoering, T. (1957), The isotopic composition of the ammonia and the nitrate ion in rain, Geochim. Cosmochim. Acta, 12(1-2), 97-102.

Honrath, R. E., M. C. Peterson, S. Guo, J. E. Dibb, P. B. Shepson, and B. Campbell (1999), Evidence of $\mathrm{NO}_{x}$ production within or upon ice particles in the Greenland snowpack, Geophys. Res. Lett., 26(6), 695-698.

Intergovernmental Panel on Climate Change (2007), Climate Change 2007: The Physical Science Basis. Contribution of Working Group I to the Fourth Assessment Report of the Intergovernmental Panel on Climate Change, Cambridge Univ. Press, Cambridge, U.K.

Janssen, C. (2005), Intramolecular isotope distribution in heavy ozone $\left({ }^{16} \mathrm{O}^{18} \mathrm{O}^{16} \mathrm{O}\right.$ and $\left.{ }^{16} \mathrm{O}^{16} \mathrm{O}^{18} \mathrm{O}\right)$, J. Geophys. Res., 110, D08308, doi:10.1029/2004JD005479.

Jarvis, J. C., E. J. Steig, M. G. Hastings, and S. A. Kunasek (2008), Influence of local photochemistry on isotopes of nitrate in Greenland snow, Geophys. Res. Lett., 35, L21804, doi:10.1029/2008GL035551.

Johnston, J. C., and M. H. Thiemens (1997), The isotopic composition of tropospheric ozone in three environments, J. Geophys. Res., 102(D21), $25,395-25,404$.

Jones, A. E., R. Weller, E. W. Wolff, and H.-W. Jacobi (2000), Speciation and rate of photochemical $\mathrm{NO}$ and $\mathrm{NO}_{2}$ production in Antarctic snow, Geophys. Res. Lett., 27(3), 345-348.

Kaiser, J., M. G. Hastings, B. Z. Houlton, T. Röckmann, and D. M. Sigman (2007), Triple oxygen isotope analysis of nitrate using the denitrifier method and thermal decomposition of $\mathrm{N}_{2} \mathrm{O}$, Anal. Chem., 79, 599607, doi:10.1021/ac061022s.

Kaleschke, L., C. Lupkes, T. Vihma, J. Haarpaintner, A. Bochert, J. Hartmann, and G. Heygster (2001), SSM/I sea ice remote sensing for mesoscale ocean-atmosphere interaction analysis, Can. J. Remote Sens., 27(5), $526-537$.

Kendall, C., E. M. Elliott, and S. D. Wankel (2007), Tracing anthropogenic inputs of nitrogen to ecosystems, in Stable Isotopes in Ecology and Environmental Science, 2nd ed., chap. 12, pp. 375-499, Blackwell, Malden, Mass.

Komatsu, D. D., T. Ishimura, F. Nakagawa, and U. Tsunogai (2008), Determination of the ${ }^{15} \mathrm{~N} /{ }^{14} \mathrm{~N},{ }^{17} \mathrm{O} /{ }^{16} \mathrm{O}$, and ${ }^{18} \mathrm{O} /{ }^{16} \mathrm{O}$ ratios of nitrous oxide by using continuous-flow isotope-ratio mass spectrometry, Rapid Commun. Mass Spectrom., 22, 1587-1596, doi:10.1002/rcm.3493.

Krankowsky, D., F. Bartecki, G. G. Klees, K. Mauersberger, K. Schellenbach, and J. Stehr (1995), Measurement of heavy isotope enrichment in tropospheric ozone, Geophys. Res. Lett., 22(13), 1713-1716.

Kunasek, S. A., B. Alexander, E. J. Steig, M. G. Hastings, D. J. Gleason, and J. C. Jarvis (2008), Measurements and modeling of $\Delta^{17} \mathrm{O}$ of nitrate in snowpits from Summit, Greenland, J. Geophys. Res., 113, D24302, doi:10.1029/2008JD010103.

Legrand, M. R., and S. Kirchner (1990), Origins and variations of nitrate in South Polar precipitation, J. Geophys. Res., 95(D4), 3493-3507.

Leighton, P. A. (1961), Photochemistry of Air Pollution, Academic Press, San Diego, Calif.

Lelieveld, J., J. van Aardenne, H. Fischer, M. de Reus, J. Williams, and P. Winkler (2004), Increasing ozone over the Atlantic Ocean, Science, 304, 1483, doi:10.1126/science. 1096777 .

Li, D., and X. Wang (2008), Nitrogen isotopic signature of soil-released nitric oxide (NO) after fertilizer application, Atmos. Environ., 42, $4747-$ 4754, doi:10.1016/j.atmosenv.2008.01.042.

Marcus, R. A. (2008), Mass-independent oxygen isotope fractionation in selected systems. Mechanistic considerations, Adv. Quantum Chem., 55, doi:10.1016/S0065-3276(07)00202-X.

McCabe, J. R., M. H. Thiemens, and J. Savarino (2007), A record of ozone variability in South Pole Antarctic snow: The role of nitrate oxygen isotopes, J. Geophys. Res., 112(12), D12303, doi:10.1029/ 2006JD007822. 
Michalski, G., Z. Scott, M. Kabiling, and M. H. Thiemens (2003), First measurements and modeling of $\Delta^{17} \mathrm{O}$ in atmospheric nitrate, Geophys. Res. Lett., 30(16), 1870, doi:10.1029/2003GL017015.

Michalski, G., J. G. Bockheim, C. Kendall, and M. H. Thiemens (2005), Isotopic composition of Antarctic Dry Valley nitrate: Implications for $\mathrm{NO}_{y}$ sources and cycling in Antarctica, Geophys. Res. Lett., 32, L13817, doi:10.1029/2004GL022121.

Moore, H. (1974), Isotopic measurement of atmospheric nitrogen compounds, Tellus, 26, 169-174.

Moore, H. (1977), The isotopic composition of ammonia, nitrogen dioxide and nitrate in the atmosphere, Atmos. Environ., 11, 1239-1243.

Morin, S., J. Savarino, S. Bekki, A. E. Cavender, P. B. Shepson, and J. W. Bottenheim (2007a), Major influence of $\mathrm{BrO}$ on the $\mathrm{NO}_{x}$ budget in the Arctic spring, inferred from $\Delta^{17} \mathrm{O}\left(\mathrm{NO}_{3}^{-}\right)$measurements during Ozone Depletion Events, Environ. Chem., 4, 238-241, doi:10.1071/EN07003.

Morin, S., J. Savarino, S. Bekki, S. Gong, and J. W. Bottenheim (2007b), Signature of Arctic surface ozone depletion events in the isotope anomaly $\left(\Delta^{17} \mathrm{O}\right)$ of atmospheric nitrate, Atmos. Chem. Phys., 7, 1451-1469.

Morin, S., J. Savarino, M. M. Frey, N. Yan, S. Bekki, J. W. Bottenheim, and J. M. F. Martins (2008), Tracing the origin and fate of $\mathrm{NO}_{x}$ in the Arctic atmosphere using stable isotopes in nitrate, Science, 322, 730-732, doi:10.1126/science.1161910.

Nakamura, K., M. Nakawo, Y. Ageta, K. Goto-Azuma, and K. Kamiyama (2000), Post-depositional loss of nitrate in surface snow layers of the antarctic ice-sheet, Bull. Glaciol. Res., 17, 11-16.

Osthoff, H. D., et al. (2006), Observations of daytime $\mathrm{N}_{2} \mathrm{O}_{5}$ in the marine boundary layer during New England Air Quality Study-Intercontinental Transport and Chemical Transformation 2004, J. Geophys. Res., 111, D23S14, doi:10.1029/2006JD007593.

Osthoff, H. D., et al. (2008), High levels of nitryl chloride in the polluted subtropical marine boundary layer, Nat. Geosci., 1, 324-328, doi:10.1038/ngeo 177 .

Patey, M. D., M. J. A. Rijkenberg, P. J. Statham, M. C. Stinchcombe, E. P. Achterberg, and M. Mowlem (2008), Determination of nitrate and phosphate in seawater at nanomolar concentrations, Trends Anal. Chem., 27(2), 169-182, doi:10.1016/j.trac.2007.12.006.

Patris, N., S. S. Cliff, P. K. Quinn, M. Kasem, and M. H. Thiemens (2007), Isotopic analysis of aerosol sulfate and nitrate during ITCT-2k2: Determination of different formation pathways as a function of particle size, J. Geophys. Res., 112, D23301, doi:10.1029/2005JD006214.

Penkett, S. A., et al. (2007), Evidence for large average concentrations of the nitrate radical $\left(\mathrm{NO}_{3}\right)$ in western Europe from the HANSA hydrocarbon database, Atmos. Environ., 41, 3465-3478, doi:10.1016/j.atmosenv. 2006.11.055.

Prospero, J. M., and D. L. Savoie (1989), Effect of continental sources on nitrate concentrations over the Pacific Ocean, Nature, 339, 687-689.

Read, K. A., et al. (2008), Extensive halogen-mediated ozone destruction over the tropical Atlantic Ocean, Nature, 453, 1232-1235, doi:10.1038/ nature 07035 .

Richter, A., F. Wittrock, A. Ladstätter-Weissenmayer, and J. P. Burrows (2002), GOME measurements of stratospheric and tropospheric BrO, Adv. Space Res., 29(11), 1667-1672.

Ridley, B. A., et al. (2000), Is the Arctic surface layer a source and sink of $\mathrm{NO}_{x}$ in winter/spring?, J. Atmos. Chem., 36, 1-22.

Rolph, G. D. (2003), Real-time environmental applications and display system (READY) Website. NOAA Air Resources Laboratory, Silver Spring, MD.,www.arl.noaa.gov/ready/hysplit4.html.

Röthlisberger, R, M. Bigler, M. A. Hutterli, S. Sommer, B. Stauffer, H. G. Junghans, and D. Wagenbach (2000), Technique for continuous high-resolution analysis of trace substances in firn and ice cores, Environ. Sci. Technol., 34, 338-342, doi:10.1021/es9907055.

Saiz-Lopez, A., A. S. Mahajan, R. A. Salmon, S. J.-B. Bauguitte, A. E. Jones, H. K. Roscoe, and J. M. C. Plane (2007), Boundary layer halogens in coastal Antarctica, Science, 317, 348-351, doi:10.1126/ science. 1141408 .

Sander, R., Y. Rudich, R. von Glasow, and P. J. Crutzen (1999), The role of $\mathrm{BrNO}_{3}$ in marine tropospheric chemistry: A model study, Geophys. Res. Lett., 26(18), 2857-2860.

Saurer, M., P. Cherubini, M. Ammann, B. De Cinti, and R. Siegwolf (2004), First detection of nitrogen from $\mathrm{NO}_{x}$ in tree rings: $\mathrm{A}{ }^{15} \mathrm{~N} /{ }^{14} \mathrm{~N}$ study near a motorway, Atmos. Environ., 38, 2779-2787, doi:10.1016/ j.atmosenv.2004.02.037

Savarino, J., and M. H. Thiemens (1999a), Analytical procedure to determine both $\delta^{18} \mathrm{O}$ and $\delta^{17} \mathrm{O}$ of $\mathrm{H}_{2} \mathrm{O}_{2}$ in natural water and first measurements, Atmos. Environ., 33, 3683-3690.

Savarino, J., and M. H. Thiemens (1999b), Mass-independent oxygen isotope $\left({ }^{16} \mathrm{O},{ }^{17} \mathrm{O}\right.$ and $\left.{ }^{18} \mathrm{O}\right)$ fractionation found in $\mathrm{H}_{x}, \mathrm{O}_{x}$ reactions, J. Phys. Chem. A, 103, 9221-9229.

Savarino, J., J. Kaiser, S. Morin, D. M. Sigman, and M. H. Thiemens (2007), Nitrogen and oxygen isotopic constraints on the origin of atmo- spheric nitrate in coastal Antarctica, Atmos. Chem. Phys., 7, 19251945.

Savarino, J., S. K. Bhattacharya, S. Morin, M. Baroni, and J.-F. Doussin (2008), The $\mathrm{NO}+\mathrm{O}_{3}$ reaction: a triple oxygen isotope perspective on the reaction dynamics and atmospheric implications for the transfer of the ozone isotope anomaly, J. Chem. Phys., 128, 194303, doi:10.1063/ 1.2917581 .

Schaap, M., et al. (2004), Artefacts in the sampling of nitrate studied in the INTERCOMP campaigns of EUROTRAC-AEROSOL, Atmos. Environ., 38, 6487-6496, doi:10.1016/j.atmosenv.2004.08.026.

Schumann, U., and H. Huntrieser (2007), The global lightning-induced nitrogen oxides source, Atmos. Chem. Phys., 7, 3823-3907.

Sigman, D. M., K. L. Casciotti, M. Andreani, C. Barford, M. Galanter, and J. K. Böhlke (2001), A bacterial method for the nitrogen isotopic analysis of nitrate in marine and fresh waters, Anal. Chem., 73, 4145-4153.

Simpson, W. R., et al. (2007), Halogens and their role in polar boundarylayer ozone depletion, Atmos. Chem. Phys., 7, 4375-4418.

Snape, C. E., C. Sun, A. E. Fallick, R. Irons, and J. Haskell (2003), Potential of stable nitrogen isotope ratio measurements to resolve fuel and thermal $\mathrm{NO}_{x}$ in coal combustion, Prepr. Am. Chem. Soc. Div. Fuel Chem., 48(1), 3-5.

Solberg, S., N. Schmidbauer, and A. Semb (1996), Boundary-layer ozone depletion as seen in the Norwegian Arctic in Spring, J. Atmos. Chem., 23 , $301-332$.

Spreen, G., L. Kaleschke, and G. Heygster (2008), Sea ice remote sensing using AMSR-E 89-GHz channels, J. Geophys. Res., 113, C02S03, doi:10.1029/2005JC003384.

Stark, H., S. S. Brown, P. D. Goldan, M. Aldener, W. C. Kuster, R. Jakoubek, F. C. Fehsenfeld, J. Meagher, T. S. Bates, and A. R. Ravishankara (2007), Influence of nitrate radical on the oxidation of dimethyl sulfide in a polluted marine environment, J. Geophys. Res., 112, D10S10, doi:10.1029/2006JD007669.

Stelson, A. W., and J. H. Seinfeld (1982), Relative humidity and temperature dependence of the ammonium nitrate dissociation constant, Atmos. Environ., 16, 983-992.

Stohl, A. (1998), Computation, accuracy and applications of trajectoriesA review and bibliography, Atmos. Environ., 32, 947-966.

Stohl, A., et al. (2007), Arctic smoke-Record high air pollution levels in the European Arctic due to agricultural fires in eastern Europe in spring 2006, Atmos. Chem. Phys., 7, 511-534.

Tarasick, D. W., and J. W. Bottenheim (2002), Surface ozone depletion episodes in the Arctic and Antarctic from historical ozonesonde records, Atmos. Chem. Phys., 2, 197-205.

Tas, E., M. Peleg, D. U. Pedersen, V. Matveev, A. P. Biazar, and M. Luria (2008), Measurement-based modeling of bromine chemistry at the Dead Sea boundary layer-Part 2: The influence of $\mathrm{NO}_{2}$ on bromine chemistry at mid-latitudes areas, Atmos. Chem. Phys., 8, 4811-4821.

Thiemens, M. H. (2006), History and applications of mass-independent isotope effects, Annu. Rev. Earth Planet. Sci., 34, 217-262, doi:10.1146/annurev.earth.34.031405.125026.

van der A, R. J., H. J. Eskes, K. F. Boersma, T. P. C. van Noije, M. van Roozendael, I. de Smedt, D. H. M. U. Peters, and E. W. Meijer (2008), Trends, seasonal variability and dominant $\mathrm{NO}_{x}$ source derived from a ten year record of $\mathrm{NO}_{2}$ measured from space, J. Geophys. Res., 113, D04302, doi:10.1029/2007JD009021.

Virkkula, A., K. Teinilä, R. Hillamo, V.-M. Kerminen, S. Saarikoski, M. Aurela, I. K. Koponen, and M. Kulmala (2006a), Chemical size distributions of boundary layer aerosol over the Atlantic Ocean and at an Antarctic site, J. Geophys. Res., 111, D05306, doi:10.1029/ 2004JD004958.

Virkkula, A., et al. (2006b), Chemical composition of boundary layer aerosol over the Atlantic Ocean and at an Antarctic site, Atmos. Chem. Phys., 6, 3407-3421.

Vrekoussis, M., E. Liakakou, N. Mihalopoulos, M. Kanakidou, P. J. Crutzen, and J. Lelieveld (2006), Formation of $\mathrm{HNO}_{3}$ and $\mathrm{NO}_{3}^{-}$ in the anthropogenically-influenced eastern Mediterranean marine boundary layer, Geophys. Res. Lett., 33, L05811, doi:10.1029/2005GL025069. Wada, E., R. Shibata, and T. Torii (1981), $\delta^{15} \mathrm{~N}$ abundance in AntarcticaOrigin of soil-nitrogen and ecological implications, Nature, 292, 327329, doi:10.1038/292327a0

Wagenbach, D., M. Legrand, H. Fischer, F. Pichlmayer, and E. W. Wolff (1998), Atmospheric near-surface nitrate at coastal Antarctic sites, J. Geophys. Res., 103(D9), 11,007-11,020.

Wagner, T., C. Leue, M. Wenig, K. Pfeilsticker, and U. Platt (2001), Spatial and temporal distribution of enhanced boundary layer $\mathrm{BrO}$ concentrations measured by the GOME instrument aboard ERS-2, J. Geophys. Res., 106(D20), 24,225-24,235.

Wagnon, P., R. J. Delmas, and M. Legrand (1999), Loss of volatile acids from the upper firn layers at Vostok, Antarctica, J. Geophys. Res., 104(D3), 3423-3431 
Weller, R., A. E. Jones, A. Wille, H.-W. Jacobi, H. P. McIntyre, W. T. Sturges, M. Huke, and D. Wagenbach (2002), Seasonality of reactive nitrogen oxides $\left(\mathrm{NO}_{y}\right)$ at Neumayer station, Antarctica, J. Geophys. Res., 107(D23), 4673, doi:10.1029/2002JD002495.

Widory, D. (2007), Nitrogen isotopes: tracers of origin and processes affecting $\mathrm{PM}_{10}$ in the atmosphere of Paris, Atmos. Environ., 41, $2382-$ 2390, doi:10.1016/j.atmosenv.2006.11.009.

Wolff, E. W., A. E. Jones, S. J.-B. Bauguitte, and R. A. Salmon (2008), The interpretation of spikes and trends in concentration of nitrate in polar ice cores, based on evidence from snow and atmospheric measurements, Atmos. Chem. Phys., 8, 5627-5634.
Yeatman, S. G., L. J. Spokes, P. F. Dennis, and T. D. Jickells (2001), Comparisons of aerosol nitrogen isotopic composition at two polluted coastal sites, Atmos. Environ., 35, 1307-1320.

F. Domine, H.-W. Jacobi, S. Morin, and J. Savarino, LGGE, 54 rue Molière, F-38400 St. Martin d'Hères, France. (samuel.morin@ujfgrenoble.fr)

M. M. Frey, BAS, High Cross, Madingley Road, Cambridge CB4 1JW, UK.

L. Kaleschke, ZMAW, Institute of Oceanography, Bundesstrasse 53, D-20146 Hamburg, Germany.

J. M. F. Martins, LTHE, CERMO, 460 rue de la Piscine, F-38400 St. Martin d'Hères, France. 